\title{
Environmental and Health Effects of Ventilation in Subway Stations: A Literature Review
}

\author{
Yueming Wen ${ }^{1} \mathbb{D}$, Jiawei Leng ${ }^{1, *}$, Xiaobing Shen ${ }^{2}$, Gang Han ${ }^{1}$, Lijun Sun ${ }^{1}$ and Fei Yu ${ }^{1} \mathbb{D}$ \\ 1 School of Architecture, Future Underground Space Institute, Southeast University, Nanjing 210019, Jiangsu, \\ China; wenyueming66@163.com (Y.W.); han_gang007@163.com (G.H.); s-lijun@163.com (L.S.); \\ 230189387@seu.edu.cn (F.Y.) \\ 2 School of Public Health, Station and Train Health Institute, Key Laboratory of Environmental Medicine \\ Engineering, Ministry of Education, Southeast University, Nanjing 210019, Jiangsu, China; \\ 101006194@seu.edu.cn \\ * Correspondence: jw_leng@seu.edu.cn; Tel.: +86-025-83790760
}

Received: 6 January 2020; Accepted: 5 February 2020; Published: 8 February 2020

check for updates

\begin{abstract}
Environmental health in subway stations, a typical type of urban underground space, is becoming increasingly important. Ventilation is the principal measure for optimizing the complex physical environment in a subway station. This paper narratively reviews the environmental and health effects of subway ventilation and discusses the relevant engineering, environmental, and medical aspects in combination. Ventilation exerts a notable dual effect on environmental health in a subway station. On the one hand, ventilation controls temperature, humidity, and indoor air quality to ensure human comfort and health. On the other hand, ventilation also carries the potential risks of spreading air pollutants or fire smoke through the complex wind environment as well as produces continuous noise. Assessment and management of health risks associated with subway ventilation is essential to attain a healthy subway environment. This, however, requires exposure, threshold data, and thereby necessitates more research into long-term effects, and toxicity as well as epidemiological studies. Additionally, more research is needed to further examine the design and maintenance of ventilation systems. An understanding of the pathogenic mechanisms and aerodynamic characteristics of various pollutants can help formulate ventilation strategies to reduce pollutant concentrations. Moreover, current comprehensive underground space development affords a possibility for creating flexible spaces that optimize ventilation efficiency, acoustic comfort, and space perception.
\end{abstract}

Keywords: subway; ventilation; environmental effect; health effect; mitigation measure; review

\section{Introduction}

Subways, a typical type of urban underground space (UUS), are the most commonly used mode of public transportation, and are gradually becoming an indispensable component of large cities. With rapid urban development, transit-oriented developments (TODs) and are gradually becoming a new urban model [1-4]. Subways, dubbed "the lifeline of urban development," connect city regions, relieve road traffic congestion, and provide hubs of interest and commerce in the underground network [5-7]. Compared with cars and buses, the subway is a low-carbon transport mode and is crucial in meeting climate goals. Today, huge populations of passengers and limited subway facilities are causing deterioration in indoor subway environments, particularly during rush hours. In China, daily passenger volumes of Beijing and Shanghai subways are more than 10 million. As a consequence, confined and crowded subway environments carry potential health risks and may trigger acute and chronic health issues as well as transmit epidemic diseases [8-12]. 
Safety and environmental health in subways has become increasingly important and attracted attention from numerous researchers in recent decades. However, the lack of long-term-effect research and limited detection technology may lead to the neglect of the environmental health effects of subways. Health effects and pathogenesis are complex due to interactions of risk factors, such as additive, synergistic, or cumulative reactions [13]. Therefore, comprehensive reviews and summaries are necessary for further research and overall environmental optimization. To date, five representative reviews [14-18] on the health effects of subways or other types of UUS show the main content of the existing research. These reviews show that there is ongoing research into environmental health in UUS, mainly in areas such as the physical environment, mental health, and human behavior. The majority of the research centers on the physical environment, particularly indoor air quality (IAQ). However, these reviews focus only on single areas (toxicology, pathology, epidemiology, environment, or engineering) and rarely examine these areas in combination and offer practical mitigation measures.

A subway space is usually isolated from the atmospheric environment, and its hermetic nature may lead to heat and moisture accumulation. Various sources of pollution can result in the accumulation, breeding, and transmission of harmful substances. Additionally, complex ambient airflows referred to as "subway climate", affects the dispersion of air pollutants, fire smoke, and biological or chemical agents [19-21]. Therefore, ventilation significantly affects the health and safety of subway passengers and workers $[10,22]$. This paper connects relevant studies from engineering, environmental, and medical aspects and discusses the environmental and health effects associated with subway ventilation systems. This paper is of certain significance to future theoretical research and practical application.

\section{Methodology}

In this paper, we have attempted to answer three crucial questions:

1. What environmental factors are affected by ventilation systems in subway stations?

2. How do these environmental factors affect human health?

3. How can ventilation improve environmental health in subway stations?

Because of the wide range of environmental and health effects, it was not feasible to conduct a single systematic review. This narrative review used the following search terms "underground space", "subsurface space", "subway", "metro", "tube", "underground railway", together with "health", "well-being", "health impact", "health effect", "health risk", "health implication", "exposure assessment", and as well as "ventilation", "filtration", "purification", "wind environment", "airflow", "air quality", "sick building syndrome (SBS)", and "building-related illness (BRI)". The search literature databases include PubMed, Medline (Ovid), Science Direct, Scopus, Google Scholar, and through websites including the Associated Research Centers for the Urban Underground Space (ACUUS), the World Health Organization (WHO), and various government websites including construction, environment, and health ministries since 1980 to 2019. As this was not a systematic but narrative review, no formal validity/quality, risk of bias assessments were done, and no exclusion criteria were applied. Through literature retrieval and analysis, the review framework expanded to other effects not previously considered, like "fire evacuation" and "noise."

\section{Results}

There has been a limited review of the health effects due to poor ventilation for both aboveground or underground buildings. Seppänen and Fisk reviewed human responses to ventilation on aboveground buildings but mainly focused on epidemiological statistics of responses and diseases [23]. Sundell et al reviewed the correlation between ventilation rates and SBS symptoms in offices [24]. More importantly, the related WHO guidelines and "The WELL building standard" briefly state some health risks and control measures [25-31]. According to the results of the literature search, as shown in Tables 1-4, ventilation directly affects human health and further, indirectly through environmental factors. Firstly, ventilation can ensure a comfortable thermal environment and inhibit the growth of 
microbes. Secondly, ventilation is indispensable to improve IAQ in subway stations. Thirdly, the complex wind environment significantly affects the draft sensation and pollutant transmission. Lastly, ventilation devices expose passengers and workers to background noise for the long term. As a result, ventilation not only acts as a mitigation measure but also a source of exposure.

Table 1. Thermal environment.

\begin{tabular}{|c|c|c|}
\hline Risk Factors & Environmental and Health Effects & Mitigation Measures \\
\hline High temperature & $\begin{array}{l}\text { - } \quad \text { Environmental effects: } \\
\text { excessive heat } \\
\text { - Health effects: heat stroke, heat } \\
\text { syncope, heat cramp, dehydration, } \\
\text { hypertension, organ dysfunction, } \\
\text { anxiety, dysphoria }\end{array}$ & $\begin{array}{l}\text { 1. Improving efficiencies and designs of } \\
\text { heating, ventilating, air conditioning, } \\
\text { and filtration systems } \\
\text { 2. Rational designs of entrances and shafts }\end{array}$ \\
\hline Low temperature & $\begin{array}{l}\text { Environmental effects: } \\
\text { cold-heat change } \\
\text { Health effects: atherosclerosis, } \\
\text { myocardial infarction, ischemic } \\
\text { heart disease, dehydration, } \\
\text { hypertension, vasoconstriction in } \\
\text { respiratory tract, rhinitis, } \\
\text { obstructive airway, susceptibility } \\
\text { to infection }\end{array}$ & $\begin{array}{l}\text { 3. Reducing internal water sources like } \\
\text { underground water seepage, toilets, } \\
\text { cleaning rooms, and equipment } \\
\text { 4. Temperature and humidity } \\
\text { independent control system } \\
\text { 5. Calculation and prediction of heat and } \\
\text { humidity loads } \\
\text { 6. Identifying reliable exposure threshold, } \\
\text { environmental indices, and comfort } \\
\text { evaluation (three other environmental }\end{array}$ \\
\hline High humidity & $\begin{array}{l}\text { Environmental effects: microbial } \\
\text { growth and air pollution } \\
\text { Health effects: perceived air } \\
\text { quality (PAQ), skin and airway } \\
\text { symptoms, functional attenuations } \\
\text { of reproductive, muscle, and } \\
\text { skeletal systems }\end{array}$ & $\begin{array}{l}\text { factors also face this challenge: } \\
\text { environmental standards specific to } \\
\text { subways based on more research on } \\
\text { toxicities of subway risks and their } \\
\text { long-term effects.) }\end{array}$ \\
\hline Low humidity & $\begin{array}{l}\text { Environmental effects: } \\
\text { virus survival } \\
\text { - } \quad \text { Health effects: PAQ, inflammatory } \\
\text { reactions in nasal and eyes, sensory } \\
\text { irritations, work performance }\end{array}$ & \\
\hline
\end{tabular}


Table 2. Indoor air quality.

\begin{tabular}{|c|c|c|}
\hline Risk Factors & Environmental and Health Effects & Mitigation Measures \\
\hline Particulate matter & $\begin{array}{l}\text { Environmental effects: } \\
\text { transmission of infectious diseases } \\
\text { - Health effects: cellular } \\
\text { inflammation and oxidation } \\
\text { reaction in multiple body systems, } \\
\text { heart disease, stroke, asthma, } \\
\text { allergy, cancer, genotoxicity }\end{array}$ & $\begin{array}{l}\text { - Preventing external infiltration: } \\
\text { Aboveground shafts and entrances away } \\
\text { from pollution sourcesInstalling and } \\
\text { cleaning composite filtration systems }\end{array}$ \\
\hline $\begin{array}{l}\text { Volatile organic } \\
\text { compound }\end{array}$ & $\begin{array}{l}\text { Health effects: PAQ; asthma, } \\
\text { allergy, nasal irritation; eye } \\
\text { irritation; cancer; genotoxicity; } \\
\text { neurological symptom }\end{array}$ & $\begin{array}{l}\text { - Limiting internal sources: } \\
\begin{array}{l}\text { 1. } \\
\text { Maintaining indoor hygiene } \\
\text { especially in cleaning } \\
\text { rooms, dustbins }\end{array}\end{array}$ \\
\hline Bioaerosol & $\begin{array}{l}\text { Environmental effects: } \\
\text { propagation and transmission of } \\
\text { microbes, antibiotic resistance and } \\
\text { transmission efficiency } \\
\text { of pathogens } \\
\text { - Health effects: pathogenic } \\
\text { mechanisms are similar in } \\
\text { different environments }\end{array}$ & $\begin{array}{l}\text { from fuel, wheel, brake, oil, } \\
\text { solvent, deodorant, and } \\
\text { decoration material } \\
\text { 3. } \quad \text { Installing air curtain, platform } \\
\text { screen door (PSD), and } \\
\text { other devices }\end{array}$ \\
\hline Others & $\begin{array}{l}\text { Environmental effect: interactions } \\
\text { with other air pollutants } \\
\text { Health effects: } \\
\text { 1. CO: neurobehavioral effect } \\
\text { 2. } \mathrm{CO}_{2} \text { : headache, nose and } \\
\text { throat ailments, } \\
\text { tiredness, fatigue } \\
\text { 3. Radon: alpha radiation, } \\
\text { lung cancer }\end{array}$ & $\begin{array}{l}\text { 1. Sufficient air exchange and } \\
\text { flexible ventilation strategy } \\
\text { 2. Optimizing ventilation mean } \\
\text { and equipment } \\
\text { 3. } \begin{array}{l}\text { Good hygiene and regular } \\
\text { maintenance of }\end{array} \\
\text { ventilation system } \\
\text { 4. Installing adsorption and } \\
\text { sterilization devices }\end{array}$ \\
\hline
\end{tabular}


Table 3. Wind environment.

\begin{tabular}{|c|c|c|}
\hline Risk Factors & Environmental and Health Effects & Mitigation Measures \\
\hline Complex airflows & $\begin{array}{l}\text { Environmental effects: } \\
\text { 1. Spreads of air pollutant and } \\
\text { fire smoke } \\
\text { 2. Overlay path of evacuee and } \\
\text { fire smoke } \\
\text { 3. } \begin{array}{l}\text { Inconsistent thermal and } \\
\text { wind environments in } \\
\text { different zones }\end{array} \\
\text { Reducing ventilation } \\
\text { efficiency and heat } \\
\text { exchange rate } \\
\text { Accumulations of heat, } \\
\text { moisture, and pollutants } \\
\text { Strong draft sensation and } \\
\text { unstable thermal sensation } \\
\text { Health effects: } \\
\text { 1. Aggravation on other } \\
\text { 2. } \begin{array}{l}\text { Acute and serious risks } \\
\text { during emergencies like fire } \\
\text { and terrorist attack }\end{array} \\
\text { Cardiovascular, respiratory, } \\
\text { 3kin, nervous, and } \\
\text { auditory responses }\end{array}$ & $\begin{array}{l}\text { 1. Zonal environmental control, } \\
\text { personalized ventilation, and variable } \\
\text { air volume system } \\
\text { 2. Limiting piston wind or other } \\
\text { airflows through PSD and air curtain } \\
\text { 3. Using piston wind through PSD } \\
\text { equipped with controllable vent and } \\
\text { (nanofiber) filter } \\
\text { 4. Hybrid exhaust system and dynamic } \\
\text { evacuation system } \\
\text { 5. Increasing fresh air volume and } \\
\text { installing high-efficiency filter } \\
\text { Optimizing velocity, temperature, and } \\
\text { location of air supply } \\
\text { Dynamic ventilation system equipped } \\
\text { with real-time monitor, multivariate } \\
\text { monitoring, multi-objective } \\
\text { optimization, feedback and } \\
\text { feedforward controllers, or } \\
\text { wearable sensor }\end{array}$ \\
\hline
\end{tabular}

Review and analysis according to the literature [18-24,238-308].

Table 4. Noise.

\begin{tabular}{|c|c|c|}
\hline Risk Factors & Environmental and Health Effects & Mitigation Measures \\
\hline Continuous noise & $\begin{array}{l}\text { Health effects: } \\
\text { 1. } \\
\text { Auditory effects: } \\
\text { noise-induced hearing loss, } \\
\text { hearing acuity, tinnitus } \\
\text { 2. } \begin{array}{l}\text { Extra-auditory effects: } \\
\text { hypertension, disturbance in } \\
\text { hormonal secretion, obesity, } \\
\text { cardiovascular disease } \\
\text { Psychological effects: } \\
\text { pressure, annoyance, } \\
\text { frustration, fatigue, sleepy, } \\
\text { apathy, insomnia, } \\
\text { cognitive impairment }\end{array}\end{array}$ & $\begin{array}{l}\text { 1. Source mitigations of track, brake, } \\
\text { ventilation machine } \\
\text { 2. Sound insulation devices like acoustic } \\
\text { enclosures and PSD with } \\
\text { microperforated panel } \\
\text { 3. Personal hearing protection device } \\
\text { 4. Acoustic design for subway space }\end{array}$ \\
\hline
\end{tabular}

Review and analysis according to the literature [17,309-318].

The structure of this paper is based on the above aspects and results. In Section 4 "Ventilation as a mitigation measure" and Section 5 "Ventilation as a source of exposure", the dual effect (Figure 1) and mechanism (Figure 2) are analyzed from the environmental effects and corresponding health effects. Meanwhile, some mitigation measures are proposed. In Section 6 "Discussion", summaries, 
questions, deficiencies, and hypotheses are discussed from three levels, from problem characteristics to assessment basis to mitigation measures.

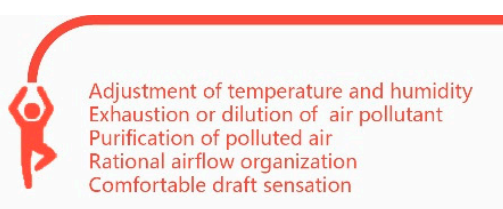

As a mitigation measure

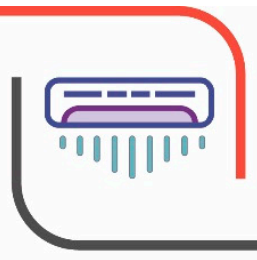

As a source of exposure

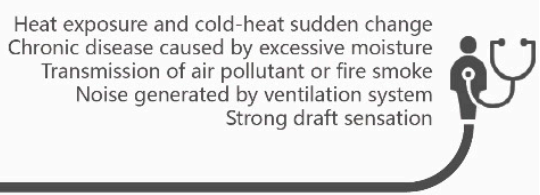

Figure 1. Dual effect of subway ventilation.
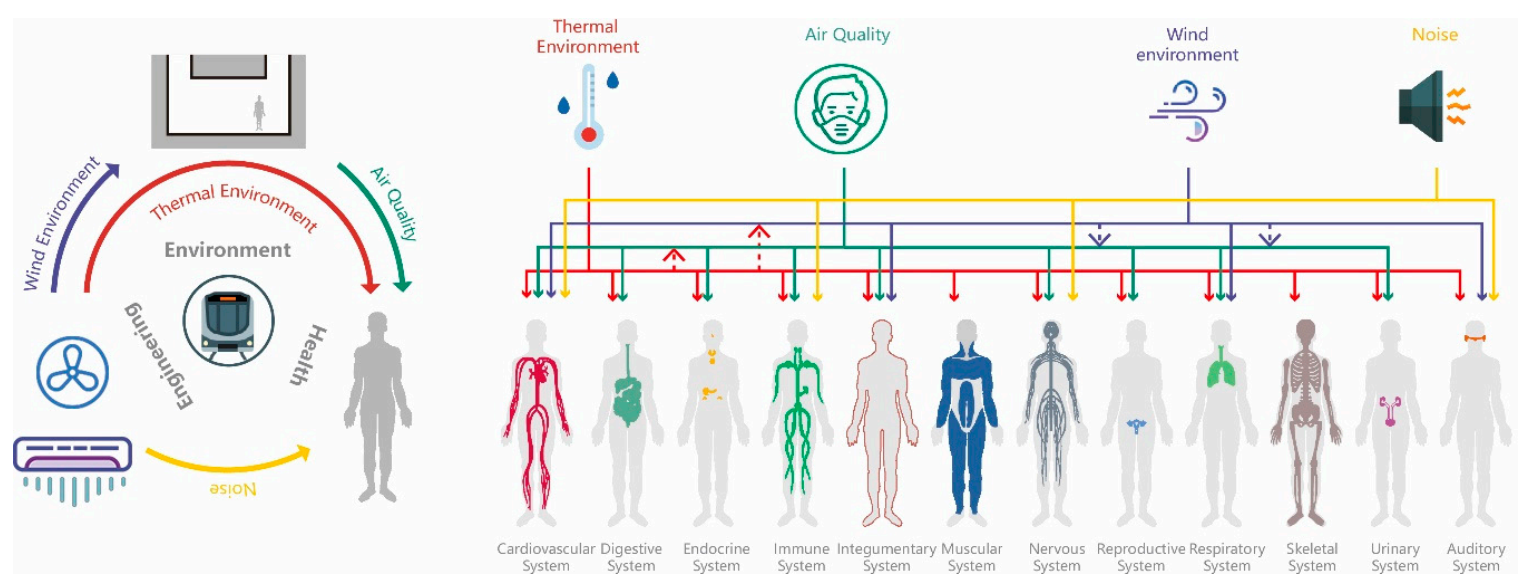

Figure 2. Mechanism of subway ventilation effects on environmental health.

\section{Ventilation as a Mitigation Measure}

Due to the limited connection with the atmospheric environment, natural ventilation is not only unable to meet the strict subway ventilation requirements but also disrupts indoor airflow. Mechanical ventilation is a reliable measure for optimizing the thermal environment and IAQ. A subway ventilation system is composed of multiple systems that cooperate and coordinate with each other, including heating, ventilating, and air conditioning (HVAC) systems and platform screen doors (PSDs). Intelligent ventilation systems are capable of adjusting their mode of operation based on external and internal conditions and thereby ensure a comfortable, healthy, thermal environment and IAQ in subway stations. The failure of a subway ventilation system to adjust the physical environment in a timely and effective manner will incur a number of health effects, which will be discussed in the following sections.

\subsection{Thermal Environment}

The thermal environment in subways significantly affects human comfort and health, as well as related environmental factors such as IAQ, airflow, and sound transmission. The water vapor condensation, humidity radiation, and indoor air pollution lead to high temperature and humidity in a subway environment. Exposure to heat and cold has extensive effects on almost every body system, including the cardiovascular, digestive, endocrine, immune, skin, muscular, nervous, reproductive, respiratory, skeletal, urinary, and auditory systems [25,31,32].

\subsubsection{Temperature}

Any impairment of thermoregulation may increase the risks of heat-related diseases [33]. The thermal environment in a subway is influenced by periodic outside climate, complex station structure, variable facility operations, and fluctuating passenger numbers. Subway gathers a considerable number of passengers within a closed space. Despite being used for a short time, uncomfortable 
temperature and humidity and poor air quality have various health effects [34-36]. Exposure to excessive heat may confuse cardiovascular, endocrine, immune, integumentary, urinary, and nervous systems and then cause physiological responses (heat stroke, syncope, cramp, dehydration, and then multiple organ dysfunctions) and heart diseases [37]. Additionally, high ambient temperature can aggravate the harm of noise on the auditory system [38] and abate digestive function [32]. Heat-related mental symptoms like anxiety and dysphoria also have serious potential risks [39].

On the contrary, a subway environment is not too cold, because it has good thermal stability and various heat sources. Nevertheless, improper ventilation may cause a cold environment or alternate heat and cold. The human body is more sensitive to cold stimuli than to warm [40]. On the one hand, sudden cold exposure can induce acute ischemic heart disease (IHD) and affects more profoundly than chronic IHD on acute myocardial infarction [41]. The physiological responses caused by cold exposure include elevated blood pressure, dehydration, atherosclerosis, and myocardial injury [42]. On the other hand, cold, dry, and windy environments can cause rhinitis, obstructive airway, and other respiratory responses [43]. Cold exposure may cause vasoconstriction in respiratory tract mucosa and suppress immune responses and barrier functions, which are responsible for increased susceptibility to infections [44-46].

\subsubsection{Humidity}

Humidity directly affects passengers' environmental perception and exerts potential risks to human health. On the one hand, high humidity can cause discomfort, especially when the relative humidity $(\mathrm{RH})$ is above $70 \%[47,48]$. Significant headaches were observed when $\mathrm{CO}_{2}$ concentrations increased to $12,000 \mathrm{ppm}$ at an $\mathrm{RH}$ of $85 \%$ [49]. Furthermore, high humidity is closely associated with the perception of odor, "stuffy air," skin, and upper airway symptoms [50-54]. Prolonged exposure to high temperature and humidity may lead to functional attenuation of reproductive, muscle, and skeletal systems $[55,56]$. On the other hand, humidity affects the formation and spread of air pollutants such as particles, aerosols, and microbes. But the underlying mechanisms among humidity, air pollutant, and human health need further studies [57-61]. High humidity may promote the accumulation and growth of microbial pathogens [62] and increase off-gassing, for example, an increase in RH of 35\% can increase the missions of formaldehyde by a factor of 1.8-2.6 [25]. Because of the limitation of ventilation, underground space usually has sufficient moisture, which provides an available condition for the growth of bacteria and fungi, in particular, filamentous fungi (mold). Therefore, preventing persistent dampness can minimize microbial pollution in subways $[62,63]$.

On the contrary, low humidity affects perceived air quality (PAQ), sensory irritations, work performance, and virus survival [58]. The perception of dry air is most likely related to sensory irritants in desiccated mucous membranes or eyes caused by insufficient ventilation resulting in air pollutants $[64,65]$. Firstly, some ophthalmologic studies showed that low relative humidity (RH) led to break-up or thinning of the eye tear film resulting in less tear production or exacerbation of water loss, which causes desiccation and hyperosmolarity in the eye tear film and initiation of a cascade of inflammatory reactions [58,66]. Secondly, both low and high RH can alter the mucous viscosity and the mucociliary activity in nasal regions, which affects bacterial adherence and penetration of foreign species. Low RH may cause desiccation or dehydration of nasal epithelium and, therefore, worsen the inflammations $[67,68]$. Thirdly, cold and low RH conditions are conducive to the survival and transmission of some influenza viruses like respiratory syncytial virus, human rhinovirus, and avian influenza virus $[57,69,70]$, but the opposite has been observed for dust-mite allergens and other virus types $[57,71,72]$.

\subsubsection{Mitigation Measures}

HVAC systems can effectively adjust the thermal environment of subway stations. However, identifying environmental indices that ensure human health remains a challenge. Evaluation standards for thermal environment include three categories, of survival, comfort, and efficiency. There are several 
evaluation indices such as teq (temperature equivalent), ET (effective temperature), $\mathrm{ET}^{*}, \mathrm{SET}^{*}$ (standard effective temperature), HIS (heat stress index), WBGT (wet bulb globe temperature index), and PMV (predicted mean vote). The PMV-PPD (predicted percentage dissatisfied) evaluation system, included in ISO (International Organization for Standardization) 7730 [73], defines a thermal environment as a function of four physical variables (air temperature, mean radiant temperature, relative air velocity, and air humidity) and two anthropogenic variables (activity level and clothing) [74]. In the popularization of the PMV-PPD system, some problems and inefficiency appear, such as climate, altitude, population density, living habits, indoor activity, sweat evaporation, and psychological expectations. Therefore, adaptive models and correction factors have been proposed to improve the suitability and accuracy of the system $[75,76]$. Thermal indices of subways should keep higher standards and change timely to cope with the changing environment, because complex airflows and crowded population may quickly deteriorate indoor environments and affect human comfort and health.

Rational designs of entrances and shafts can prevent outdoor rain, moisture, and cold air from entering subway stations. To be more specific, first, entrances and shafts should be kept away from underground water, streets, and close to urban air corridors and wind directions, so that air pollutants or heat can be removed quickly from aboveground surroundings. Next, roof, barricade, air curtain, and green wall can prevent rainwater and cold wind from entering the station. Then, increasing length, section, and area of entrance channel, and installing an HVAC system obviously buffer inside and outside temperature differences. Finally, plane shapes of entrance channels, such as linear, broken linear, or L-shaped, can be designed according to the demand of using piston wind. Additionally, controlling water seepage and accumulation in tunnels reduces the sources of humidity and air pollutants. Similarly, controlling the water sourced from station toilets, cleaning rooms, and equipment improves the thermal conditions and IAQ. Furthermore, the condensate water of the air-conditioning system is still a problem, which produces mold and other microbes. Conventional air-conditioning systems share a cold source and simultaneously cools and dehumidifies the air to remove heat and moisture. Because of the temperature difference between cooling (below the air) and dehumidification (below the dew point), conventional systems increase energy waste and condensate water, because they can only accurately control one parameter of temperature or humidity and hence, cause an uncomfortable sensation of "too cold" or "stuffy". Temperature and humidity independent control systems can address this problem and adjust flexibly for different subway zones $[77,78]$. In this independent control system, the liquid desiccant system engages all fresh air load and indoor wet load and adjusts the air supply humidity. Meanwhile, the high-temperature chiller engages most of the indoor sensible heat load and adjusts the air supply temperature. Additionally, calculation and prediction of heat and humidity loads need further studies due to the variations of cold air infiltration, passenger flow, and heat source in subways.

\subsection{IAQ}

Confined subway spaces tend to accumulate air pollutants generated from indoor or outdoor [7982]. Although passengers usually use subways for about one hour a day (20 minutes in stations), it is enough to expose passengers to an unhealthy environment and the environmental hygiene in the carriages is usually worse than in the stations. In Barcelona, commuters spend about $3 \%$ of the day in the subway, but this microenvironment may account for up to $47 \%$ of the total particulate matter (PM)2.5 daily dose [83]. Besides, lots of inhalable particulate matters generate inside subways and thus have differences from PMs entering from outside [80,84-87]. Hence, it is necessary to specialize in the health effects of subway air. Several representative reviews summarized the research process and primary objects of IAQ in subways $[16,18,80,86]$. Based on these reviews, particulate matters (PMs), volatile organic compounds (VOCs), and bioaerosols are three main factors affecting IAQ. Also, other excessive or deficient air components can affect human health such as $\mathrm{CO}, \mathrm{CO}_{2}, \mathrm{NO}_{2}$, and $\mathrm{O}_{3}$. Instead of establishing a logic for health risk control, these reviews focused on certain aspects of health effects. This paper clarifies a path of air pollutants from generation to impact to reduction. Sources and 
compositions are the basis of controlling pollutant generations and studying their toxicities. Although relevant studies aboveground have certain reference significances, studies specialized in subway pollutants are more conducive to formulate environmental indices for risk control.

\subsubsection{PMs}

PMs are the most concerned research object of air pollutants in subways. Subway PMs' sources are from both outdoor and indoor: (1) aboveground atmosphere and surrounding environment, and (2) underground tunnels, stations, facilities, and passengers. The compositions and characteristics of subway PMs are mainly determined by indoor sources, including mechanical wear, material degradation, tunnel dust, and human activities like cleaning. Wheel and brake pads, steel rails, and power supply materials give the particles a peculiarly metalliferous character. Subway PM concentrations are directly affected by frequency of train, commuter influx, ventilation system, surrounding air, soil resuspension, construction year, station depth, and other pollutant concentrations [11,80,86-109]. Because of the complexity of the indoor and outdoor environments, there is no consistent composition of subway PMs. The main components are metal, total carbon (TC), and secondary inorganic aerosol (SIA) [97,108,110-113]. Firstly, subway PMs are highly ferruginous (FePM) and accompanied by trace metals, such as $\mathrm{Mn}, \mathrm{Cr}, \mathrm{Cu}, \mathrm{Sb}, \mathrm{Ba}, \mathrm{Zn}$, and $\mathrm{Mo}$, of which the dominant ferruginous component is typically oxidized to magnetite, maghemite, and hematite [88,90,94,96,102,103,106,110,114-137]. Secondly, carbonaceous PM is the first or second most abundant component in subways, especially platforms [110,138-141]. Thirdly, the crustal particles (mainly silicates) are not only from the mineral dust in infiltrated outdoor air but also from construction material and rock soil inside subways. Halite and secondary inorganic compounds like water-soluble nitrate, sulfate, and ammonium are rare in subway air and usually infiltrate from outside [80,98,110,111,121,137].

PMs of different sizes can reach different human organs and exert specific health effects [142]. Smaller PMs penetrate deeper parts of the lungs and do more harm. For the people with the same susceptibility and exposure time, exposure doses are mainly dependent on particle sizes and concentrations [83]. Furthermore, PMs may combine with other air pollutants and generate secondary pollutants, such as nitrogen oxides [143]. PMs' concentration presents spatiotemporal characteristics in subways. Urban environments, meteorological variations, subway conditions, applied technologies, route choices, and personal habits all lead to variable exposure levels to air pollutants. Therefore, it is difficult to conclude a meaningful global average for conditions above or below ground [80,144]. In general, PM concentrations measured on subway platforms are several times higher than those recorded simultaneously outside [79,83,104,110,115,145-148].

Studies on pathological and toxicological responses of the human body provide a quantitative basis. Nevertheless, research on cell damage and the health effects of specific physical properties or chemical compositions of subway particles are still insufficient $[80,149]$. Inhaled PMs can cause cellular inflammation, reactive oxygen, and genotoxic effects and induce acute and chronic responses in different body systems such as skin, ocular, respiratory, and cardiovascular systems. These responses may increase the incidences of heart disease, stroke, allergy, asthma, cancer, and infectious diseases [150,151]. Despite a controversy over the hazards of subway air compared with ground air, there is a consensus on the oxidative potential (OP) of subway PMs. However, oxidation mechanisms of subway PMs are controversial. Some earlier studies implicated that ferruginous nature was responsible for the OP of subway PMs. However, Moreno suggested that although Fe dominated the composition of subway PMs, it was not responsible for oxidative damage and that more likely candidates were the trace metals such as Mn, Zn, Ba, and especially Cu [80,86,99,120,152-168].

\subsubsection{VOCs}

Subway environments expose passengers to a high level of VOCs, particularly during rush-hours. Subways account for $10 \%-20 \%$ of daily VOC exposure [169]. The longer the passengers stayed in 
subways, the higher their VOC exposure. Existing research mainly includes aromatic hydrocarbons, carbonyls and chlorinated hydrocarbons ( $\mathrm{CHs}$ ), especially polycyclic aromatic hydrocarbons (PAHs), toluene, HCHO (formaldehyde), and acetaldehyde [138,169-177]. In this paper, HCHO is discussed in the VOCs section, although this is controversial in different IAQ guidelines.

Subway VOCs have complex sources of indoor emissions and outdoor infiltrations [80,139,169,170, 174,177-180]. PM-bounded VOC is an important transmission form that is convenient for sampling, measurement, and trace tracking. Firstly, research on aromatic hydrocarbons mainly focus on PAHs and BTEX (benzene, toluene, ethylbenzene, xylenes) and indicates that the highest exposure risk is benzene. Traffic-related emission is a dominant source of BTEX through indoor and outdoor air exchange $[139,169,174,180]$. BTEX also has many indoor sources, like accidentally spilled oil and various solvents $[169,174,177]$. Concentrations of aromatic hydrocarbons are mainly affected by seasonality, rail maintenance activities, passenger numbers, outdoor air, and ground transports $[80,139,174]$. Meanwhile, underground fast-food courts, restaurants, and shopping malls may bring VOCs into subways through airflows [174]. Secondly, carbonyls mainly come from the automobile exhaustion or incomplete combustion of fossil fuels [181]. However, subway trains do not use fossil fuel but electric power. As a result, subway carbonyls mainly come from outdoor air and keep to low levels. Indoor sources also include passengers, materials, and solvents. Besides, ozone chemistry can help to generate aldehydes by reactions with VOCs and unsaturated organic chemicals $[170,178,179]$. HCHO is the most abundant carbonyl, followed by acetaldehyde and acetone. Concentrations of carbonyls correlate with years of carriages and stations, area, and depth of platforms [179,182]. Although the concentrations meet some health standards, there still exist health risks of VOCs when long-term subway users are exposed to a certain time and doses $[170,173,174,178,179,183-185]$. Thirdly, CHs source from indoor and outdoor air exchange or products containing chlorinated solvents. For example, trichloroethylene and para-dichlorobenzene come from cleaning and deodorizing products through vapor intrusion from toilets and underground water [174].

VOCs affect the human body through inhalation, ingestion, and dermal sorption $[179,186]$. Exposure to VOCs, particularly those classified as known or suspected carcinogens like benzenes, aldehydes, and ketones, potentially exert adverse effects on human health. Besides, VOCs are essential precursors of many secondary pollutants, which in turn deteriorate IAQ $[4,170,174,179,187]$. Because PAHs have different carcinogenic activities, their concentrations are not appropriate means for health risk assessments. Better means to estimate the carcinogenic potency of the compounds are to multiply their respective concentrations and toxic equivalency factor (TEF) values. Benzo(a)pyrene (B(a)P) and dibenzopyrene isomers are appropriate indicators for TEF to assess total health risk. $\mathrm{B}(\mathrm{a}) \mathrm{P}$ had the highest carcinogenic potency, but some PAHs still lack toxicological data, TEF values, or analytical methods $[172,183,188]$. In addition to cancer risk, VOCs also have other adverse effects. Some PAHs are genotoxic, such as B(a)P [139]. Formaldehyde may stimulate respiratory, skin, ocular, and nervous systems, increase incidences of asthma or allergy, and cause DNA adduct formation and clastogenic effects [81,189]. Additionally, the long-term effects of subway VOCs need more data and studies $[170,176]$.

\subsubsection{Bioaerosols}

Bioaerosols refer to aerosols containing biological particles, such as bacteria, fungi, viruses, and parasite eggs, and have infectivity, pathogenicity, and allergenicity. Subways are high-risk places for microbial growth and propagation due to various sources, thermal environment, limited ventilation, and crowded population [190-192]. Existing research mainly focuses on concentration level, diversity, sources, and virulence- and survival-associated properties. Worldwide field research shows different microbial components in subways, of which common microbes include aspergillus, alternaria, bacillus, cladosporium, chrysosporium, geotrichum, micrococcus, propionibacterium, penicillium, and staphylococcus [190,191,193-199]. 
Sources and compositions of microbes are affected by various factors such as humans, soil, water, outdoor air, location, depth, and building materials [98,190,192,195-198,200-202]. First, according to genera comparisons, subway microbes are closely associated with the human body and activity [190, 200,201]. Foods and garbage produced by passengers also pollute indoor microbial environments [203]. Next, continuous and efficient air exchanges maintain healthy microbial concentrations and make microbial species in subways similar to outside air [201]. Especially during off-peak hours, size distributions of subway bioaerosols are similar to that of outside air [204]. Leung et al. compared microbial communities in Hong Kong with those in the United States and founded different microbial clustering based on continental geography [190]. Then, shallow stations highly correlate with the outdoor conditions $[205,206]$. Deep tunnels provide a specific microenvironment reflecting indoor air, which may significantly influence the fungal species composition [202,207]. Finally, common genera from the underground mycobiota are well known as a biological detergent of building material, which may serve as a permanent source of underground air pollutants [202].

Bioaerosol concentrations have strong time dependence and condition dependence. On the one hand, bioaerosol emissions during peak hours are much higher than those during off-peak hours [190,192,193,204,208], and concentrations in spring are higher than those in winter, which may correlate to higher outside temperatures and snow melting [196,202]. Meanwhile, the number of passengers and frequencies of trains may increase concentrations and transmissions of subway microbes [191,192,194,202,206,209,210]. Additionally, Heo and Lee suggested that concentrations of bacterial aerosols were affected by the number of passengers, but fungal aerosols were slightly affected by seasonal changes and human activities [211]. On the other hand, conditions of stations, tunnels, and facilities basically affect microbial concentrations. Depths of the subway stations positively correlate with microbial concentrations. Older subways presented worse microbial environments. Furthermore, as a major environmental control mean, polluted ventilation systems do great harm to microbial environments [190,196,210,212-214].

Pathogenic mechanisms of microbes are similar even in different environments. Crowded passengers increase microbial sources and deteriorate physical environments in subways. Increases in indoor temperature, humidity, and carbon dioxide indirectly promote microbial growth. Besides, crowded environments enhance antibiotic resistance and pathogen transmissions [191,197]. The pathogenicity potential of subway microbes has been controversial. Some research shows that fungal concentrations are significantly lower than bacterial ones in subways, and not severe enough to cause disease $[202,206,215,216]$. However, bacteria, together with fungal propagules, can cause respiratory disease. Risks of "mold"-allergic diseases do exist during peak hours [202].

\subsubsection{Other Air Components}

Other air compositions in subways also exert potential risks on passengers. $\mathrm{CO}, \mathrm{CO}_{2}, \mathrm{NO}_{2}$, and other air compositions rapidly accumulate in subway stations and carriages due to confined spaces, huge populations, and various sources. CO usually remains at a relatively low level because fossil fuels and smoking are prohibited [81], but CO can affect human neurobehavior through combining with toluene and monocyclic aromatic hydrocarbons [171]. When it comes to $\mathrm{CO}_{2}$, its concentrations closely correlate with passenger numbers. When $\mathrm{CO}_{2}$ concentration exceeds $1000 \mathrm{ppm}$, occupants may complain about headaches, nose and throat ailments, tiredness, lack of concentration, and fatigue $[81,217,218]$. Additionally, radon exposes respiratory tissues to alpha radiation and increases incidences of lung cancer, but concentrations of airborne radon in subways are usually below admissible dosages [219-222].

\subsubsection{Mitigation Measures}

In short, mitigation measures for IAQ aim at reducing pollutant concentrations and can be summarized into three aspects: (1) preventing external infiltration, (2) limiting internal sources, and (3) eliminating or diluting pollutants. 
Firstly, air exchanges with ambient atmosphere may bring harmful substances into subways such as PMs, VOCs, microbes, allergens, moisture, and waste heat. Hence, aboveground ventilation shafts and entrances should be designed away from pollution sources. Furthermore, efficient filtrations are essential to prevent pollutant infiltrations. Filtration systems affect not only fresh air quality but also heat exchange rates of subway ventilation [223]. On the one hand, magnetic mesh filters have a certain capture efficiency for metallic PMs [224-226]. For easy cleaning and controllable magnetic field density, it is recommended to use electromagnets in a magnetic hybrid filter system [225,227]. On the other hand, composite filtration systems are not a simple superposition of purification technologies, but a combination of different technologies to achieve complementary advantages [228]. In recent years, HVAC systems for new subways are equipped with electrostatic purification devices in air-conditioning units or windpipes, which can effectively reduce PM concentrations and remove organic pollutants, bacteria, and microbes through physical separations [229-231]. Apart from magnetic filters and electrostatic purification devices, there are many applicable purification technologies to specific pollutants: (1) fiber filtration to PMs, microbes, and radon, (2) activated carbon to PMs, $\mathrm{NO}_{2}$, and VOCs, (3) photocatalysts to VOCs and microbes, (4) negative ion to PMs, bacteria, and fungi, (5) ultraviolet to bacteria and fungi, and (6) plasma to PMs, VOCs, bacteria, and viruses [228,231,232]. However, these air purification technologies may cause other pollution problems such as ozone, nitrogen oxides, and other harmful gases produced in the process of electrostatic disinfection [229].

Secondly, various internal sources are more challenging in confined subways. Pollutants from passengers are difficult to control, and toilets, cleaning rooms, dustbins, and facilities are inevitable subway operations. Hence, mitigations mainly depend on controlling pollutant transmissions and cleaner materials. On the one hand, early ventilation designs depend on simple fresh air systems and winds driven by thermal pressure and train motion that bring polluted airflows from tunnels to whole stations. Hence, unreasonable ventilations become a source of exposure, which is discussed in detail in the next chapter. Zonal controls, air curtains, and PSDs have been installed to prevent polluted airflows from flowing into passenger zones. On the other hand, preventing emissions of harmful substances can radically reduce environmental risks. Applying liquid dust suppressants to new ballasts, prohibiting diesel-powered trains or facilities, building along a straight, horizontal trajectory, designing a variable longitudinal profile railway, and slowing trains at sharp curves and high gradients may minimize wears of rail, wheels, and brakes, and then reduce metallic PM emissions. Besides, developments of materials that emit fewer and less toxic particles are a positive way forward [5,82,233-236]. When it comes to VOCs, controlling ground fossil-fueled vehicles effectively decreases the VOC concentrations in subways [177], and restricted use and prompt cleaning of spilled oils, solvents, deodorants, and decoration materials can reduce indoor sources. For bioaerosols, reducing PMs can limit bioaerosol formations. Meanwhile, it is essential to inhibit the growth of microbes through regulating thermal and humid conditions, reducing porous materials, maintaining environmental hygiene, and installing sterilization facilities.

Thirdly, although adsorption and sterilization devices can gradually eliminate some pollutants, they cannot meet the instantaneous huge demand in the subway which accommodates a large number of passengers. Hence, exhausting or diluting air pollutants through sufficient air exchanges and flexible ventilation strategies dominates IAQ controls of subways. Displacement ventilations are efficient air exchange means widely used to reduce indoor pollutants. They supply fresh air at very low-velocity levels at or near the floor level and then rise, driven by thermal stratifications, to bring pollutants to the surface, which allows pollutants to leave breathing areas and be removed more easily [25]. Meanwhile, good hygiene and regular maintenance are of prime importance in reducing adverse effects of ventilation systems [23,190,191,194,202,204,206,213,237]. Additionally, based on aerodynamic characteristics of different pollutants, CFD (computational fluid dynamics) simulations are of great significance for formulations of ventilation strategies. 


\section{Ventilation as a Source of Exposure}

While optimizing the physical environment, a subway ventilation system also carries potential health risks that cannot be overlooked, such as transmission of air pollutants and generation of uncomfortable draft sensations. A subway is a whole network with its own climatic conditions, which significantly affect the ambient airflow and pollutant transmission. Air pollutants can originate from a myriad of sources, including the external atmosphere, underground tunnels, cleaning chemicals, and equipment, and may spread throughout subway stations. To adjust the complex wind environment, flexible design and efficient operation of comprehensive mechanical ventilation and environmental control systems are required. However, ventilation systems that are in continuous operation and under heavy loads are more prone to pollution by PMs and microbes. The hygiene of ventilation systems is always a problem. It has been found that indoor microbe pollution is closely associated with poor ventilation system hygiene. Several mitigation measures have been proposed, including regular cleaning of baffle plates and filters, the use of cooling systems, and, particularly, strictly controlling temperature and humidity in subway stations $[78,238,239]$. Moreover, extensive and instantaneous air exchange may result in the formation of high-speed airflow. If coupled with the train-induced wind, the airflows can cause uncomfortable draft sensations and even skin, respiratory, or cardiovascular conditions. Furthermore, noise inside a subway station is difficult to transmit outside to the external environment and produces worse and longer-term effects due to the closed, sound-proof underground space. While accounting for only a limited proportion of the total noise in a subway station, noise generated by the ventilation system is the most persistent and should be minimized. In the following section, ventilation is discussed as a source of exposure associated with health risks from wind environment and noise perspectives.

\subsection{Wind Environment}

Wind environments in subways are affected by mechanical ventilation, outside winds, buoyancy-driven airflows, train-induced winds (piston winds), or a combination of the above factors. The airflows that spread air pollutants from one space to another may cause IAQ problems in multiple indoor areas. Airflows from various pollutant sources inside and outside subways all bring air pollutants into subway stations. Airflows generated by passengers and trains cause resuspensions of settled pollutants [192]. These airflows all increase concentrations of air pollutants and affect pollutant discharge efficiencies. Wind environments also depend on building geometry, pollution sources, thermal/fluid boundary conditions, and ventilation designs like ventilation rate, location of supply outlets and return outlets, and diffuser characteristics [240].

Unlike aboveground office and residential buildings, subways only have several ventilation vents or station exits with limited sizes for air exchanges. High ventilation rates and frequent facility utilizations require ventilation systems to keep their cleanliness and efficiency to ensure abundant clean air entering subways. Furthermore, some recent energy-saving studies propose to utilize piston winds through train movement [241-244] and buoyancy-driven airflows through hot pressing [245], which make wind environments and pollutant transmissions more complicated. Spaces and airflows in subways are so complex that they cannot merely introduce fresh air to dilute and then exhaust air outside. According to pollutant sources, pressure differences, and cleaning standards in different subway areas, ventilation needs flexible designs, predictive analyses, and real-time adjustments.

Fire evacuation is another serious potential risk associated with subway ventilations. Ventilations and smoke exhausts should not only exhaust smoke efficiently but also ensure the separation of humans and smoke because fire smokes have high temperatures and immediate risks to humans. On the one hand, fire smokes include several toxic gases, especially CO. CO can quickly cause dyspnea and poisoning symptoms. A high-density smoke also reduces the visibility of evacuees [246-248]. Besides, hot smokes and fires may damage subway constructions [249]. On the other hand, initial airflows are generated by piston effects or pressure differences and affect later movements of fire smokes in an initial period [250]. For a reasonable and effective evacuation strategy, it is indispensable to study the 
background airflows in subway microenvironments [20,21]. The strategy "go up and take the nearest exit to the surface" may not be the best response, because fire smokes or toxic airborne substances tend to use the same routes as fleeing passengers [248]. Tsukahara et al. simulated a large-scale and multistory station that had a fire source on a middle floor and concluded that downward evacuations could be more effective than upward ones [246]. However, dynamic evacuation guidance is more applicable and safe according to smoke distributions and passenger positions $[248,251]$.

\subsubsection{Complex Airflows}

Firstly, "subway climatology" was defined by Pflitsch in the late 1990s, which referred to natural airflows caused by temperature differences between subways and outer atmospheres. Because temperatures inside subways are generally higher than those outside from the late summer to winter, penetrating cold airs and rising warm airs at subway openings to external atmospheres drive natural airflow in tunnels. Therefore, such climates significantly affect dispersions of airborne substances $[19,252,253]$. For CFD combined with pedestrian simulations with tracer gas experiments [254], dynamic evacuation systems based on subway climatology take into account locations of passengers, transmissions of air pollutants, and subway climate at that time. These systems can identify the most endangered areas and guide passengers via an adaptive route using audio and visual techniques $[20,21,248]$.

Secondly, piston winds affect human health through IAQ, thermal comfort, and draft sensation. Piston winds are generated by vehicle motion and blow through whole stations. Piston winds force a large number of air pollutants or cold air into subway stations because their speeds significantly exceed the design values of ventilation systems [255]. Hence, piston winds seriously disorder operations of ventilation systems $[80,256,257]$. In 2013, Pan et al. systematically reviewed the piston effect in subway stations from the aspects of formation mechanisms, simulation analyses, environmental effects, and control measures [242]. Based on the review of Pan et al., the latest health-related studies are reviewed. On platforms, piston winds are generally weaker in the middle than at both ends [257], and higher PM concentrations usually occur at train entry points of platforms due to air turbulences caused by piston wind $[80,91,96,258]$. Hence, passengers should reduce time spent on platforms and wait for trains in the middle parts of platforms, which requires mitigations of space designs, and platform staff need frequent breaks and to regularly change working positions [257]. In tunnels, number, geometrical structure, linkage angle, and location of vent shafts and train frequencies directly affect the performance of piston winds [241,259-263]. Additionally, barriers placed at tunnel outlets [264] and partitioning blocks installed along the middle of the tunnels [265] can improve ventilation performance.

Thirdly, without mechanical ventilation and piston wind, stack effects dominate airflows to move towards stairwells, elevator shafts, and ventilation shafts, and may spread fire smokes throughout subway stations. Preliminary designs of subway spaces and environmental controls decide the performance of stack effects. Under the same condition, areas and locations of shafts usually predominate airflows, and areas are more dominant than locations [250]. Furthermore, replacing vertical shafts with tilted shafts can eliminate boundary layer separations to optimize smoke exhausts [266]. Pressure differences induced by stack effects are much larger than those caused by other driving forces like gas combustions or winds $[250,267,268]$. Hence, the pressure settings of ventilation systems need flexible adjustments between different areas.

\subsubsection{Mitigation Measures}

Mitigations of wind environments in subways are comprehensive systems, which require coordinated operations of multiple systems. Firstly, zonal control is the most feasible for complex thermal and wind environments in subways. Especially at transfer stations or multilevel stations, zonal control can meet various ventilation requirements to maintain a consistent indoor environment. Secondly, using and limiting piston winds are difficult problems to maintain environmental health in subways. Thirdly, air supplies closely correlate with draft sensations and ventilation efficiencies, which 
are common problems in subways. Fourthly, mechanical smoke exhaust should ensure safe evacuations of passengers in emergency situations such as fire or a biological attack. Lastly, dynamic ventilation systems can adjust ventilation strategies to stable subway environments and energy conservations through computer technology and real-time monitoring. Corresponding mitigation measures of the above five aspects are analyzed in detail below.

Firstly, zonal environmental controls and personalized ventilation systems can limit the spread of air pollutants to a certain extent and maintain a unified comfort level. In general, there are three zones in subways: station hall, platform, and tunnel. Each area is composed of multiple functional areas or rooms. In terms of health risk, platforms almost isolate from the outside atmosphere and are the most complex subway zones, which are directly affected by polluted airs from station halls and tunnels. Platforms gather numerous passengers and intractable pollution sources like toilets, cleaning rooms, and machine rooms $[148,215]$. Increasing fresh air volumes and installing high-efficiency filters in ventilation systems can effectively reduce pollutant concentrations [148]. To be more specific, displacement ventilation seems to be the most promising for creating a better IAQ and an acceptable thermal comfort level indoors $[25,269]$. Displacement ventilation based on square column attachment has superior performance of ventilation efficiencies and thermal comforts compared to traditional mixing ventilations $[270,271]$. Meanwhile, considering air velocity, air temperature, age of air, and relative warmth index (RWI), Liu et al. assessed air distributions by adopting three different air supply schemes (mixing ventilation, stratified air ventilation, and air curtain ventilation) for a subway platform and demonstrated that air curtain ventilation presented an appropriate velocity and temperature distribution [22]. Hence, air curtains can be installed at the boundaries of different subway areas to control airflows. Additionally, tunnel ventilations are another influencing factor of platform IAQ and affect airflow directions between tunnels and platforms. Tunnel fans can introduce outside air or exhaust inside air under different conditions. Tunnel ventilation may reduce both mass concentrations and number concentrations of PMs on platforms by over 50\%, even in the presence of full-length PSDs [272,273]. Furthermore, although installing PSDs reduce PM concentrations in platforms, it increases PM concentrations in tunnels and still affects passengers' health in trains [274].

Secondly, air curtains and PSDs are major devices to control piston winds. On the one hand, air curtains can effectively control unsteady airflows to improve ventilation efficiencies, ensure comfortable draft sensations, and reduce energy consumptions [243,255,275]. However, when the outside temperatures are below $-10{ }^{\circ} \mathrm{C}$ in severe cold regions, warm-air curtains at the entrance individually consume massive energy and may not prevent intrusions of cold air from outside. In this situation, controlling speeds of trains entering and leaving stations can reduce cold air entering stations [276]. Meanwhile, changing air resistance coefficients and structures of traditional curtains may adjust relationships of inlet and outlet air volumes and make use of waste heat from subway operations [243]. On the other hand, PSDs prevent air pollutants, especially PM10, from tunnels to platforms. PSDs have five research areas including IAQ, fire smoke, thermal environment, energy conservation, and airflow analysis [219,277-285]. PSDs with controllable vents are wildly attentional environmental control systems. Through coordination between controllable vents and HVAC devices, these systems adjust operation modes based on platform heating loads, outdoor weather conditions, and tunnel air temperatures. With controllable vents closed in air-conditioning seasons, environmental control systems operate as traditional PSD systems to prevent polluted air from entering platforms. With controllable vents open in non-air-conditioning seasons, these systems operate as platform bailout door (PBD) systems and take full use of piston effects to ventilate and remove wasted heat from stations [244,283]. Meanwhile, PSDs prevent objects or passengers from falling off platforms and reduce noises from trains and fans [286].

Thirdly, velocities, temperatures, and locations of air supplies directly affect environmental health and human health. The vertical temperature gradient presents a significant variation in subway stations [22]. Deep and multi-story stations are a trend of subway designs, which exacerbate energy losses of downward airflows and cause poor ventilation areas [247]. A reasonable design of air supply 
systems can provide adequate fresh air and comfortable draft sensation in every subway area and make the 'dead zone' of ventilation disappear [287]. Meanwhile, air supplies should maintain consistent draft and thermal sensations when passengers move from one area to another [35]. Additionally, Wang et al. studied coupling airflows between air-conditioning air supplies and piston winds in a platform without PSDs. They showed that piston winds led to an increase in heat dissipation from human skin. Comfort levels under air-conditioning airflows alone were better than those of coupling airflows. However, these coupling airflows may improve transitional thermal comforts and have huge energy-saving potentials in air-conditioning systems by increasing air temperatures of air supplies [288,289].

Fourthly, mechanical exhaust systems can ensure passengers' safety in case of fires or biochemical attacks. On the one hand, due to the flexibility and reliability, hybrid exhaust systems are more suitable for subway environments. Integrated utilization of mechanical and natural ventilation effectively inhibit fire smoke dispersions and decrease toxic substance concentrations [290]. Smoke exhaust systems in tunnels and platforms can operate collaboratively to deal with different situations [291]. Meanwhile, smoke control systems in subways consist of tunnel ventilation fans, under platform exhaust systems, smoke evacuating gates, and platform edge doors. Smoke control systems actively control smoke movements and ensure passenger safety $[250,267]$. On the other hand, there are some measures to improve efficiencies of existing smoke exhaust systems, such as breadthways ventilations in low-height platforms without a ceiling duct [287], equivalent vent velocities in long smoke removal pipes [292], heat exhaust coefficients for tunnel transversal smoke extraction system [293], and ventilation strategies for smoke-free staircases [294].

Lastly, subway IAQs significantly change in real-time due to various time-dependent factors such as subway schedules, passenger loads, and outdoor climates. [295]. For quick responses in controlling subway IAQs, real-time monitors, multi-objective optimizations, and dynamic control systems can improve the performance of ventilation systems by adjusting equipment, strategies, and rates [273,295-302]. Variable air volume systems can dynamically meet ventilation requirements with less energy consumption and comfortable thermal condition [303,304]. Marzouk and Abdelaty presented an application that utilized a wireless sensor network and building information modeling to monitor thermal conditions in subways [305]. Furthermore, multivariate monitoring and local interpretation of IAQs better isolate air quality characteristics that vary seasonally and allow for more specific monitoring of air pollutants [306]. As discussed above, outdoor air quality (OAQ) around subways significantly affects the IAQ. Hence, OAQ monitoring systems with feedback and feedforward controllers can forecast IAQ changes and adjust ventilation strategies in advance [299]. Additionally, to reduce errors caused by sensor faults, an air pollutant prediction model based on an adaptive network-based fuzzy inference system was used to detect sensor fault, and a structured residual approach with maximum sensitivity method was used to identify and reconstruct sensor faults existing in subway system [307]. However, dynamic data of the above studies were from periodic measurements of air quality monitoring stations, which may be insufficient to provide precise data for assessing individual environmental risks. Wearable sensors are more suitable to provide estimations of IAQ in the proximity of passengers, which can provide necessary information on health risks for passengers to make travel arrangements that minimize exposure to polluted air [308].

\subsection{Noise}

Noise generated by ventilation systems constitutes a limited part of subway noise but lasts the longest. Long-term exposure to environmental noise can have a number of health effects $[309,310]$. The primary sources of subway noise include subway operation, public broadcasting, and human activities. Regular noise caused by subway operation can be categorized into several types, namely, wheel/rail noise, machine noise, traction noise, and brake noise, of which, wheel/rail noise contributes the most to the total noise. A questionnaire-based study conducted by Wang et al. found that over $90 \%$ of the respondents agreed that subway stations, particularly transfer stations and during rush hours, were noisy [311,312]. Therefore, reducing the noise level is beneficial to ensuring a healthy subway 
environment. There are some conflicts between sound insulation and ventilation requirements. For example, PSDs can effectively reduce train and fan noise in tunnels [311] but affect the use of piston winds. In addition, tubular subway spaces are usually long, narrow, and low, and therefore have long reverberation times and poor language clarity [312]. Spatial acoustic designs for conventional subways have a multitude of defects and require further research.

\subsubsection{Continuous Noise}

Noises have adverse effects on psychological, biological, immunological, and endocrine systems [313]. Because few studies focus on the proportion and quantity of ventilation noise, this paper summarizes related effects based on whole noises in subways, which include auditory, extra-auditory, and mental effects. Firstly, there are some long-term and incremental auditory effects such as noise-induced hearing loss, tinnitus, and unnoticeable diminution in hearing acuity. Auditory effects are caused by mechanical damage to inner ears. Subway noises exceed limit values recommended by Environmental Protection Agency and $\mathrm{WHO}$, which indicate exposure duration should be shorter than 45 minutes under a mean noise level of about $85 \mathrm{dBA}$. The maximum noise levels of platforms or carriages were even higher than 100 dBA [314]. Secondly, extra-auditory effects include hypertension, disturbance in hormonal secretion, cardiovascular diseases, and obesity. Exposure to high levels of noise may result in elevation of cholesterol, triglycerides, lipoproteins, and blood pressure and then affect cardiovascular, respiratory, and central nervous systems [313,314]. Thirdly, mental effects include psychological pressure, annoyance, frustration, fatigue, sleepiness, apathy, insomnia, and memory problems. Although noise-related effects are explained in relation to central nervous systems, secondary and tertiary reactions are not controlled by brain cortexes, which may reduce corporal and mental functions in the long-term. Exposure to noise in the long-term also causes a reaction of exhaustion or defeat which leads to disturbance in the secretion of some hormones such as the growth hormone, catecholamine [315,316], possibly followed by dysfunction of immune systems. Additionally, noises have adverse effects on concentration, work capacities, human communications, and increase accident risks [314,317].

\subsubsection{Mitigation Measures}

Reduction measures for subway noise can be classified into four categories: source mitigations of tracks, such as braking mechanisms, ventilation machines [314], sound insulation devices like acoustic enclosures [311] or PSDs with microperforated panels [311,312], personal hearing protection devices [314], and acoustic designs for subway spaces [312]. Additionally, temperature and humidity in subways can affect values of sound reverberations and speech intelligibility [318]. Health risk assessments of ventilation noises need further studies to provide exposure thresholds and environmental indices.

\section{Discussion}

Subways have gradually become the most used UUS for urban residents on a daily basis. Therefore, it is important to pay attention to exposure risks associated with subway microenvironments and establish their control standards, evaluation systems, and mitigation toolbox [319]. However, there is insufficient awareness of the potential for long-term health effects of the subway environment. Subway passengers need a healthy environment with comfortable temperature, humidity, and draft conditions, as well as clean indoor air. Ventilation is the most important measure for adjusting the physical environment in a subway station but may also cause serious health issues in the absence of rational design and continuous operation.

\subsection{Dual Effect of Subway Ventilation on Environmental Health}

Through a narrative literature review, a distinguishing feature of subway ventilation was uncovered in this study, that is, subway ventilation exerts a dual effect, as both a mitigation measure and a source of exposure. The accumulation of heat, moisture, and air pollutants inside a subway station dictates the health level of its environment in normal time. Deterioration of the thermal environment can cause 
adverse responses in almost every body system, and then increase disease incidence. Temperature and humidity also exert indirect health effects by affecting other environmental factors such as PAQ, microbial pollution, and pressure difference. When it comes to IAQ in subways, PMs, VOCs, and bioaerosols are sources of exposure of the most concern. Metallic PM and the resulting oxidation potentials are viewed as representative risks that affect environmental health in subways and have been extensively analyzed through pathological studies and simulations. Health risks of VOCs, which are carcinogenic and genetically toxic, may be underestimated due to their complex sources, delayed effects, and insufficient toxicity studies. Humid environments and ventilation systems provide conditions for the growth and spread of microbes and bioaerosols. These problems can be addressed using efficient ventilation. However, ventilation is a double-edged sword, due to the lack of a source of totally clean air in subways. First, natural airflows caused by pressure difference and piston wind may bring polluted air or fire smoke throughout the subway station and thereby worsen IAQ. Then, the humid condition, huge load, continuous operation, and fixed installation all render it difficult to maintain a clean ventilation system. Moreover, high-speed air supply causes uncomfortable draft sensations that may affect passengers' integumentary, respiratory, and cardiovascular systems. Finally, noise will be amplified in the closed subway space. Continuous noise generated by ventilation systems should be minimized. Overall, ventilation exerts not only direct effects on human health and comfort but also indirect effects by affecting other environmental factors. Notwithstanding, ventilation is an indispensable measure for controlling the indoor environment in a subway station. Hence, it requires a more comprehensive design, flexible adjustment, and continuous maintenance.

\subsection{Reliable and Specific Environmental Health Risk Assessment}

Further research is required to study some problems related to environmental health in subways. In terms of medicine and epidemiology, the exposure threshold, disability-adjusted life year (DALY), acceptable daily intake (ADI), and other indices are controversial on some risks. The correlations and differences between experiments in vitro and in vivo complicate the formulation of these indices. It is, therefore, necessary to take into consideration whether there are environmental influences or interactions between pathogenic factors when studying pathogenic mechanisms and exposure thresholds. Long-term epidemiological surveys may be more reliable than toxicity tests. Furthermore, life cycle impact assessment models require further improvement to comprehensively assess the health effects and not only use physicochemical and toxicological properties but also other relevant parameters combined with environmental characteristics, such as the USEtox method [320]. More specifically, the potential effects of indoor humidity on air pollution and human health can still benefit from further research. More research into subway air pollution should be conducted to examine the suitability and reliability of the reference aboveground indices. Additionally, more research is also required to optimize detection technology and exposure assessment techniques to reduce equipment-related differences between studies.

Based on reliable exposure thresholds and maximum acceptable concentrations, environmental health indices can be used to control health risks more effectively. A number of countries and organizations have published health-based environmental control guidelines or standards, as shown in Table 5. In addition to these intuitive indices, attention should also be drawn to some potential microenvironmental changes. For example, sudden temperature changes can severely affect comfort and even trigger acute cardiovascular events when passengers pass through different areas inside or outside a subway station. This is a common problem in most subway stations, particularly those that serve as major transport hubs and those in cold or tropical climates. This problem may be addressed by dynamic thermal comfort assessments and body condition monitoring. Through zonal ventilation control, the gradual change or stable condition of the thermal environment in a subway station can be adjusted on the temperature difference and human comfort. Additionally, it is also necessary to establish assessment systems specifically for subway IAQ that fully account for the pathogenic and spatiotemporal characteristics of pollutants in subway environments. 
Table 5. Environmental control indices of relevant standards or guidelines.

\begin{tabular}{|c|c|c|c|c|c|}
\hline $\begin{array}{l}\text { Environmental Control } \\
\text { Factors Related to } \\
\text { Ventilation }\end{array}$ & $\begin{array}{l}\text { WHO Guideline for Indoor Air } \\
\text { Quality and Occupational Health } \\
\text { (WHO) }\end{array}$ & $\begin{array}{l}\text { The WELL Building Standard-V1 } \\
\text { (US Green Building Council, } \\
\text { ASHRAE) }\end{array}$ & $\begin{array}{l}\text { Hygienic Indicators and } \\
\text { Limits for Public Places } \\
\text { (China) }\end{array}$ & $\begin{array}{l}\text { Indoor Environmental } \\
\text { Input Parameters } \\
\text { (CEN) }\end{array}$ & $\begin{array}{l}\text { Environmental Health Management Standard } \\
\text { for Buildings } \\
\text { (Japan) }\end{array}$ \\
\hline $\begin{array}{l}\text { TEMP } \\
\left({ }^{\circ} \mathrm{C}\right)\end{array}$ & $\begin{array}{c}16 ~ 28 \\
\text { (Healthy residence) }\end{array}$ & Graphic Comfort Zone Method & $26 \sim 28$ & $20 \sim 26$ & $17 \sim 28$ \\
\hline $\begin{array}{l}\mathrm{RH} \\
(\%)\end{array}$ & $\begin{array}{c}45 \sim 75 \\
\text { (Microbial inhibition) }\end{array}$ & $30 \sim 50$ & $40 \sim 65$ & $30 \sim 65$ & $40 \sim 70$ \\
\hline $\begin{array}{c}\mathrm{PM}_{2.5} \\
\left(\mu \mathrm{g} / \mathrm{m}^{3}\right. \\
\text { 24-hour mean })\end{array}$ & 25 & 35 & - & 25 & \multirow{2}{*}{$\begin{array}{c}150 \\
\text { (Suspended dust) }\end{array}$} \\
\hline $\begin{array}{c}\mathrm{PM}_{10} \\
\left(\mu \mathrm{g} / \mathrm{m}^{3}\right. \\
\text { 24-hour mean })\end{array}$ & 50 & 50 & 150 & - & \\
\hline $\begin{array}{c}\mathrm{HCHO} \\
\left(\mu \mathrm{g} / \mathrm{m}^{3}\right. \\
\text { 1-hour mean }) \\
\end{array}$ & 100 & $\begin{array}{c}27 \\
\mathrm{ppb}\end{array}$ & 100 & 100 & 100 \\
\hline $\begin{array}{c}\text { TVOC } \\
\left(\mu \mathrm{g} / \mathrm{m}^{3}\right. \\
\text { 8-hour mean })\end{array}$ & 300 & 500 & 600 & $300 \sim 1000$ & 400 \\
\hline $\begin{array}{l}\text { Total bacteria } \\
\left(\mathrm{CFU} / \mathrm{m}^{3}\right)\end{array}$ & $200 \sim 500$ & - & 4000 & - & - \\
\hline $\begin{array}{c}\mathrm{CO} \\
\text { (mg/m } \\
\text { 8-hour mean })\end{array}$ & 10 & 10 & 10 & 15 & $\begin{array}{c}10 \\
\mathrm{ppm}\end{array}$ \\
\hline $\mathrm{CO}_{2}$ & $\begin{array}{l}1000 \\
\text { ppm }\end{array}$ & $\begin{array}{r}800 \\
\text { ppm }\end{array}$ & $0.15 \%$ & $\begin{array}{c}1000 \sim 2000 \\
\text { ppm }\end{array}$ & $\begin{array}{l}1000 \\
\text { ppm }\end{array}$ \\
\hline $\begin{array}{c}\mathrm{O}_{3} \\
\left(\mu \mathrm{g} / \mathrm{m}^{3}\right. \\
\text { 8-hour mean })\end{array}$ & 100 & 100 & 160 & 60 & $\begin{array}{c}0.1 \\
\mathrm{ppm}\end{array}$ \\
\hline $\begin{array}{c}\text { Radon } \\
\left(\mathrm{Bq} / \mathrm{m}^{3},\right. \\
\text { annual mean) }\end{array}$ & 100 & 148 & 400 & 100 & - \\
\hline $\begin{array}{l}\text { Air change flow } \\
\left(\mathrm{m}^{3} /(\mathrm{h} \text {-pers })\right)\end{array}$ & - & 41.65 & 30 & 25.2 & - \\
\hline $\begin{array}{l}\text { Wind speed } \\
(\mathrm{m} / \mathrm{s})\end{array}$ & - & 0.15 & 0.5 & - & 0.5 \\
\hline $\begin{array}{l}\text { Noise } \\
(\mathrm{dB}(\mathrm{A}))\end{array}$ & 85 & 40 & 85 & 60 & 60 \\
\hline
\end{tabular}

Abbreviations: WHO (World Health Organization); CEN (Comité Européen de Normalisation, European Committee for Standardization); ASHRAE (American Society of Heating, Refrigerating and Air-Conditioning Engineers); TEMP (Temperature); RH (Relative Humidity); PM (Particulate Matter); TVOC (Total Volatile Organic Compound). "Indoor environmental input parameters" refers to the recommended parameters of Category II for normal level in the standard "Indoor environmental input parameters for design and assessment of energy performance of buildings addressing indoor air quality, thermal environment, lighting, and acoustics" published by CEN. 


\subsection{Ventilation Mitigation to Improve Environmental Health}

Ventilation not only significantly affects the thermal and humid environment in a subway station but also plays a vital role in air pollutant transmission and air pollutant-related infection. On the one hand, integrated and intelligent ventilation systems can improve IAQ and conserve energy in subway stations [80,233,241-244]. In a subway station, piston winds, hot pressures, the stack effect, and the subway climate can all increase the ambient airflow, regardless of whether the mechanical ventilation system is in operation. However, the airflow may originate from sources of pollution inside and outside the subway station. Hence, it is essential to install composite filtration systems to purify air. Some filtration-related problems need, however, to be tackled, including rapid efficiency reduction, difficulties in removing built-up pollutants, emergency disinfection, sterilization capacity, and automated monitoring, cleaning, and alarm technologies. On the other hand, zonal and dynamic control systems can be employed to control the complex and changeable wind environment in a subway station and adjust the mechanical ventilation mode in a flexible and timely manner to prevent the spread of air pollutants or fire smoke. When it comes to specific measures, air curtains, PSDs, and interior space design are effective measures to block polluted airflow and fire smoke. PSDs with controllable vents can be used to simultaneously take advantage of piston winds and block PMs by installing nanofiber filters [321]. However, although the above measures can block complex airflow movement, ventilation strategies for piston wind should be adjusted flexibly in different climate zones. For example, subway stations in cold zones are shielded by PSDs and air curtains to reduce the penetration of external cold air caused by piston winds in winter. But these stations in tropical zones need piston winds in the summer to release internal heat and reduce HVAC loads. Therefore, how to design and control ventilation shortcuts for piston winds so that pollutants and heat can be exhausted quickly from platforms to outside might make sense. Additionally, an understanding of the aerodynamic and reproductive characteristics of air pollutants can help formulate corresponding environmental indices and ventilation strategies.

Another potential problem is various interactions between different ventilation strategies. On the one hand, ventilation measures described in the previous paragraph inevitably result in an inconsistent environment in a subway station characterized by variable conditions (temperature, humidity, air quality, pressure, wind speed, and age of air) as well as dirty "dead zone" and uncomfortable draft sensations. Therefore, subway ventilations need comprehensive design and flexible adjustment through real-time monitoring, demand forecasting, timely feedback, and other dynamic ventilation strategies. On the other hand, synergistic or inhibitory interactions exist in different ventilation strategies, which echoes the dual effect of subway ventilation. Large air volume can effectively discharge air pollutants and improve IAQ, but also reduce efficiencies of cooling or heating systems, affecting the thermal comfort of passengers. Meanwhile, the ventilation strategy of using piston wind to exhaust heat can cause draft sensations, especially in narrow spaces, and cause the spread of air pollutants to whole stations. Among these interactions, a significant problem is some defects of ventilation paths and space design in traditional subway stations. Therefore, it is necessary to emphasize the impact of space design on environmental health in subway stations. Arguably, a rational space design is the basis for efficient ventilation. Adverse effects of unreasonable subway spaces are hardly compensated by traditional ventilation-based design patterns of environmental control systems. Compared with ventilation systems, spatial connection and airflow movement dominate the spreading of airflow movement and thermal comfort in subway stations, which is a basic problem more or less neglected by previous studies and engineering design. Meanwhile, spatial acoustic design, to a certain extent, affects subway noise control. The subway environment is significantly affected by its interior space factors, including shape, size, material, connection and separation of spaces, and the number, location, and size of vertical shafts, stairs, and exits. In architectural and interior design, there are often some spaces or components that block smoke movement and exhaustion [250]. For example, vertical walls will result in smoke backflow and increase smoke temperature under the ceiling [249]. Compared to conventional tubular spaces, large atria are beneficial when it comes to ensuring fire safety in subway stations because they can 
allow smoke and heat to accumulate close to the ceiling and accelerate smoke exhaustion [290,322]. In a subway tunnel, partition blocks installed between two tracks can reduce the airflow effect on one track induced by train motions on the other track and enhance the piston effect [265]. With the integrated utilization of underground spaces and developments of underground engineering, further research is required to investigate more systematic spatial patterns on the improvement of environmental health. For example, atriums between station halls and platforms provide significant relief from high-speed piston winds, because they eliminate narrow airflow lanes, like stairs channels. Meanwhile, atriums, combined with effective smoke blocking devices like smokescreen and smoke-preventing air curtains, can effectively transport air pollutants and fire smoke to the top of atriums and then exhaust outside through ventilation shafts. Compared with the conventional strategy of limiting smoke in horizontal layers, this strategy has obvious advantages in exhausting smoke, reducing thermal damage of constructions, and organizing evacuation paths. Furthermore, atriums are conducive to shaping a comfortable spatial scale that may reduce the psychological effects of underground spaces. Based on the discussion in this subsection, a prototype of subway stations with ideal ventilation and space environments, which is derived from various research findings and integrated into a conceptual diagram, is shown in Figure 3.

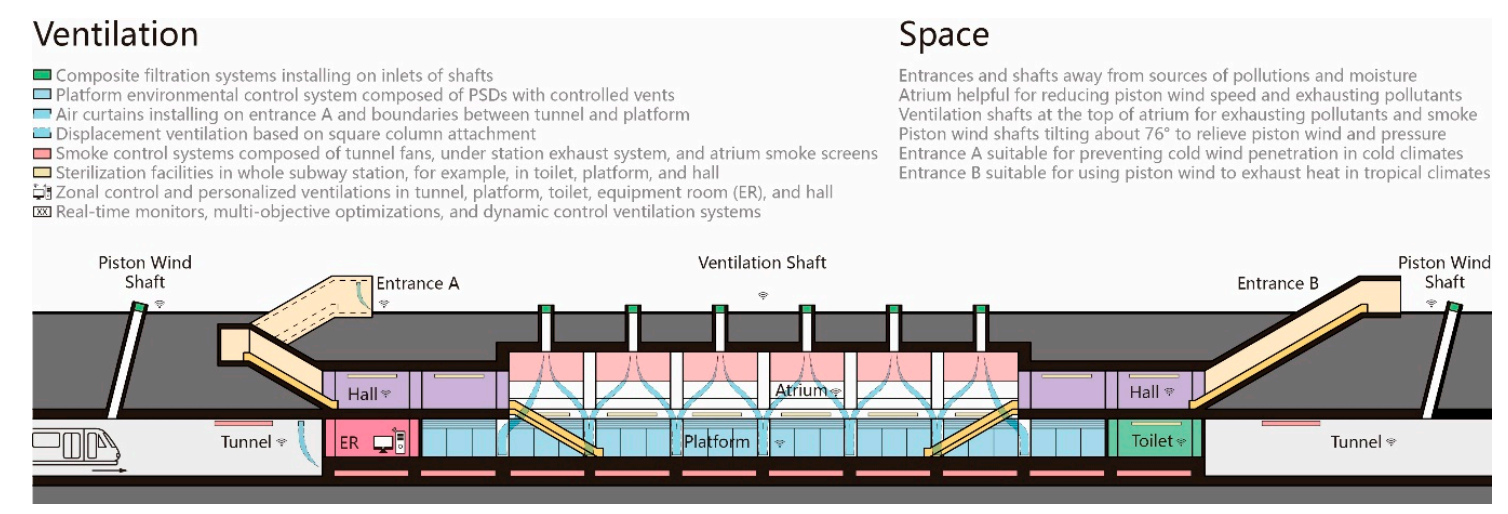

Figure 3. An ideal ventilation and space environment for subway stations.

\section{Conclusions}

This study clarifies the complex relationship between ventilation and human health in subway stations from the perspectives of pathology, epidemiology, engineering, and built environment. Recommend exposure thresholds or values from medical and epidemiological studies that offer a basis for health risk assessment and environmental control are discussed. Health risk assessments of subways should further integrate specific toxicology research of subway pollutants, long-term epidemiological data, and environmental characteristics of subways. Based on these data, engineering measures can be implemented to effectively improve environmental health in subway stations. In short, ventilation exerts a notable dual effect on environmental health in subway stations. Ventilation, on the one hand, is a dispensable measure for optimizing the physical environment in a subway station and, on the other hand, can potentially negatively affect its wind and acoustic environment. Wind environments are more complex in subway stations than in aboveground buildings due to various pollution sources, limited ventilation inlets/outlets, and strong background airflows caused by piston wind and subway climate. Ventilation systems in subway stations not only should introduce clean, fresh air and dilute and/or discharge air pollutants, but also should be controlled zonally and adjusted in real-time. It is necessary to simulate and analyze the effects of variable airflow combined with the aerodynamic behavior of various air pollutants. Additionally, space optimization, as the basis of efficient ventilation, has not received enough attention in the past due to limited construction technologies and immature professional cooperation. Unreasonable space connections and ventilation paths may cause a series of adverse effects and contradictions, which are hardly compensated by ventilation systems and devices. In the traditional design pattern of a subway environment, space precedes ventilation, and ventilation 
remedies space, which should be replaced by a more comprehensive design pattern. The coupling relationship between space and ventilation should be considered at an early stage, and the organization strategy of internal and external airflow should be determined according to regional climate and environmental conditions.

Author Contributions: Conceptualization, J.L., Y.W., and X.S.; Methodology, J.L. and Y.W.; Software, Y.W.; Formal analysis, J.L., Y.W., and X.S.; Investigation, Y.W., G.H., L.S., and F.Y.; Data curation, J.L. and Y.W.; Writing-original draft preparation, Y.W.; Writing-review and editing, J.L., Y.W., and X.S. All authors have read and agreed to the published version of the manuscript.

Funding: This research received no external funding.

Acknowledgments: The authors gratefully thank Raymond Leslie Sterling from Louisiana Tech University for his suggestions on the review.

Conflicts of Interest: The authors declare no conflict of interest.

\section{References}

1. Loo, B.P.Y.; Chen, C.; Chan, E.T.H. Rail-based transit-oriented development: Lessons from New York City and Hong Kong. Landsc. Urban Plan. 2010, 97, 202-212. [CrossRef]

2. Papa, E.; Bertolini, L. Accessibility and Transit-Oriented Development in European metropolitan areas. J. Transp. Geogr. 2015, 47, 70-83. [CrossRef]

3. Sung, H.; Oh, J.-T. Transit-oriented development in a high-density city: Identifying its association with transit ridership in Seoul, Korea. Cities 2011, 28, 70-82. [CrossRef]

4. Yang, J.; Chen, J.; Le, X.; Zhang, Q. Density-oriented versus development-oriented transit investment: Decoding metro station location selection in Shenzhen. Transp. Policy 2016, 51, 93-102. [CrossRef]

5. Reche, C.; Moreno, T.; Martins, V.; Minguillón, M.C.; Jones, T.; de Miguel, E.; Capdevila, M.; Centelles, S.; Querol, X. Factors controlling particle number concentration and size at metro stations. Atmos. Environ. 2017, 156, 169-181. [CrossRef]

6. de Vasconcellos, E.A. Urban transport, environment, and equity. In The Case for Developing Countries/Eduardo Alcântara Vasconcellos; Earthscan: London, UK, 2001; ISBN 185383727X.

7. Wallace, M.I.; Ng, K.C. Development and application of underground space use in Hong Kong. Tunn. Undergr. Space Technol. 2016, 55, 257-279. [CrossRef]

8. Cooley, P.; Brown, S.; Cajka, J.; Chasteen, B.; Ganapathi, L.; Grefenstette, J.; Hollingsworth, C.R.; Lee, B.Y.; Levine, B.; Wheaton, W.D.; et al. The role of subway travel in an influenza epidemic: A New York City simulation. J. Urban. Health 2011, 88, 982-995. [CrossRef] [PubMed]

9. Goscé, L.; Johansson, A. Analysing the link between public transport use and airborne transmission: Mobility and contagion in the London underground. Environ. Health 2018, 17, 84. [CrossRef] [PubMed]

10. Kim, M.; Braatz, R.D.; Kim, J.T.; Yoo, C. Indoor air quality control for improving passenger health in subway platforms using an outdoor air quality dependent ventilation system. Build. Environ. 2015, 92, 407-417. [CrossRef]

11. Kwon, S.-B.; Jeong, W.; Park, D.; Kim, K.-T.; Cho, K.H. A multivariate study for characterizing particulate matter (PM(10), $\mathrm{PM}(2.5)$, and $\mathrm{PM}(1))$ in Seoul metropolitan subway stations, Korea. J. Hazard. Mater. 2015, 297, 295-303. [CrossRef]

12. Song, J.; Lee, H.; Kim, S.-D.; Kim, D.-S. How about the IAQ in Subway Environment and Its Management? AJAE 2008, 2, 60-67. [CrossRef]

13. ASHRAE. ASHRAE GUIDELINE 10-2016. Interactions Affecting the Achievement of Acceptable Indoor Environments. ASHRAE, 2016. Available online: https://www.techstreet.com/ashrae/standards/guideline10-2016-interactions-affecting-the-achievement-of-acceptable-indoor-environments?product_id=1929023 (accessed on 7 February 2020).

14. Carmody, J.C.; Sterling, R. Design considerations for underground buildings. Undergr. Space 1984, 8, 352-362.

15. Gershon, R.R.M.; Qureshi, K.A.; Barrera, M.A.; Erwin, M.J.; Goldsmith, F. Health and safety hazards associated with subways: A review. J. Urban. Health 2005, 82, 10-20. [CrossRef] [PubMed]

16. Loxham, M.; Nieuwenhuijsen, M.J. Health effects of particulate matter air pollution in underground railway systems-A critical review of the evidence. Part. Fibre Toxicol. 2019, 16, 12. [CrossRef] [PubMed] 
17. Khaing, N.E.E.; Abuduxike, G.; Posadzki, P.; Divakar, U.; Visvalingam, N.; Nazeha, N.; Dunleavy, G.; Christopoulos, G.I.; Soh, C.-K.; Jarbrink, K.; et al. Review of the potential health effects of light and environmental exposures in underground workplaces. Tunn. Undergr. Space Technol. 2019, 84, 201-209. [CrossRef]

18. Xu, B.; Hao, J. Air quality inside subway metro indoor environment worldwide: A review. Environ. Int. 2017, 107, 33-46. [CrossRef]

19. Pflitsch, A.; Küsel, H. Subway-Climatology_New Research Field for the Management of Possible Catastrophes in Subway Systems; Man and Climate in the 20th Century, University of Wroclaw: Wroclaw, Poland, 2003.

20. Qian, Z. Integrated Evaluation of Air Flow and Gas. Dispersion for Underground Station Safety Strategies Based on Subway Climatology; Newcastle University: Newcastle, UK, 2017.

21. Brüne, M.; Charlton, J.; Pflitsch, A.; Agnew, B. The Influence of subway climatology on gas dispersion and the effectiveness of guided evacuations in a complex subway station. Meteorol. Z. 2016, 25, 489-499. [CrossRef]

22. Liu, C.; Li, A.; Yang, C.; Zhang, W. Simulating air distribution and occupants' thermal comfort of three ventilation schemes for subway platform. Build. Environ. 2017, 125, 15-25. [CrossRef]

23. Seppänen, O.A.; Fisk, W.J. Summary of human responses to ventilation. Indoor Air 2004, 14 (Suppl. 7), 102-118. [CrossRef]

24. Sundell, J.; Levin, H.; Nazaroff, W.W.; Cain, W.S.; Fisk, W.J.; Grimsrud, D.T.; Gyntelberg, F.; Li, Y.; Persily, A.K.; Pickering, A.C.; et al. Ventilation rates and health: Multidisciplinary review of the scientific literature. Indoor Air 2011, 21, 191-204. [CrossRef]

25. International WELL Building Institute. The WELL Buiding Standard v1 2019. Available online: https: //resources.wellcertified.com/tools/well-building-standard-v1/ (accessed on 7 February 2020).

26. WHO Regional Office for Europe. WHO Air Quality Guidelines for Particulate Matter, Ozone, Nitrogen Dioxide and Sulfur Dioxide 2005. Available online: http://www.euro.who.int/en/health-topics/environmentand-health/air-quality/publications/pre2009/air-quality-guidelines.-global-update-2005.-particulatematter,-ozone,-nitrogen-dioxide-and-sulfur-dioxide (accessed on 7 February 2020).

27. WHO Regional Office for Europe. Who Guidelines for Indoor Air Quality. Dampness and Mould 2009. Available online: https://www.who.int/airpollution/guidelines/dampness-mould/en/ (accessed on 7 February 2020).

28. WHO Regional Office for Europe. WHO Guidelines for Indoor Air Quality. Selected Pollutants 2010. Available online: http://www.euro.who.int/en/health-topics/environment-and-health/air-quality/publications/2010/ who-guidelines-for-indoor-air-quality-selected-pollutants (accessed on 7 February 2020).

29. World Health Organization. WHO Handbook on Indoor Radon. a Public Health Perspective 2009. Available online: https://www.who.int/ionizing_radiation/env/9789241547673/en/ (accessed on 7 February 2020).

30. World Health Organization. WHO Guidelines for Indoor Air Quality. Household Fuel Combustion 2014. Available online: https://www.who.int/airpollution/guidelines/household-fuel-combustion/en/ (accessed on 7 February 2020).

31. World Health Organization. Ambient Air Pollution. A Global Assessment of Exposure and Burden of Disease 2016. Available online: https://www.who.int/phe/publications/air-pollution-global-assessment/en/ (accessed on 7 February 2020).

32. Li, X. Research status of multi-organ damage caused by hyperthermia. Occup. Health 2017, 33, 1149-1152.

33. Kovats, R.S.; Hajat, S. Heat stress and public health: A critical review. Annu. Rev. Public Health 2008, 29, 41-55. [CrossRef] [PubMed]

34. Alhorr, Y.; Arif, M.; Katafygiotou, M.; Mazroei, A.; Kaushik, A.; Elsarrag, E. Impact of indoor environmental quality on occupant well-being and comfort: A review of the literature. Int. J. Sustain. Built Environ. 2016, 5, 1-11. [CrossRef]

35. Sinha, K.; Rajasekar, E. (Eds.) Assessment of Transient Thermal Comfort Characteristics in an Underground Metro Station; Network for Comfort and Energy Use in Buildings: Windsor, UK, 2018.

36. Ampofo, F.; Maidment, G.; Missenden, J. Underground railway environment in the UK Part 1: Review of thermal comfort. Appl. Therm. Eng. 2004, 24, 611-631. [CrossRef]

37. Oudin Åström, D.; Åström, C.; Forsberg, B.; Vicedo-Cabrera, A.M.; Gasparrini, A.; Oudin, A.; Sundquist, K. Heat wave-related mortality in Sweden: A case-crossover study investigating effect modification by neighbourhood deprivation. Scand. J. Public Health 2018. [CrossRef] 
38. Wang, Y.-J.; Wang, M.-K.; Ding, M.; Wang, X.-H.; Zhou, H.-Y. Health Effects of Combined Exposure to Noise and High Temperature. Prog. Mod. Biomed. 2014, 14, 5175-5179.

39. Thompson, R.; Hornigold, R.; Page, L.; Waite, T. Associations between high ambient temperatures and heat waves with mental health outcomes: A systematic review. Public Health 2018, 161, 171-191. [CrossRef]

40. Lv, Y.-G.; Liu, J. Effect of transient temperature on thermoreceptor response and thermal sensation. Build. Environ. 2007, 42, 656-664. [CrossRef]

41. Davídkovová, H.; Plavcová, E.; Kynčl, J.; Kyselý, J. Impacts of hot and cold spells differ for acute and chronic ischaemic heart diseases. BMC Public Health 2014, 14, 480. [CrossRef]

42. Liu, C.; Yavar, Z.; Sun, Q. Cardiovascular response to thermoregulatory challenges. Am. J. Physiol. Heart Circ. Physiol. 2015, 309, H1793-H1812. [CrossRef]

43. Cruz, A.A.; Naclerio, R.M.; Proud, D.; Togias, A. Epithelial shedding is associated with nasal reactions to cold, dry air. J. Allergy Clin. Immunol. 2006, 117, 1351-1358. [CrossRef] [PubMed]

44. Mourtzoukou, E.G.; Falagas, M.E. Exposure to cold and respiratory tract infections. Int. J. Tuberc. Lung Dis. 2007, 11, 938-943. [PubMed]

45. Castellani, J.W.; M Brenner, I.K.; Rhind, S.G. Cold exposure: Human immune responses and intracellular cytokine expression. Med. Sci. Sports Exerc. 2002, 34, 2013-2020. [CrossRef] [PubMed]

46. Jaakkola, K.; Saukkoriipi, A.; Jokelainen, J.; Juvonen, R.; Kauppila, J.; Vainio, O.; Ziegler, T.; Rönkkö, E.; Jaakkola, J.J.; Ikäheimo, T.M. Decline in temperature and humidity increases the occurrence of influenza in cold climate. Environ. Health 2014, 13, 22. [CrossRef]

47. Jin, L.; Zhang, Y.; Zhang, Z. Human responses to high humidity in elevated temperatures for people in hot-humid climates. Build. Environ. 2017, 114, 257-266. [CrossRef]

48. Han, J.; Kwon, S.-B.; Chun, C. Indoor environment and passengers' comfort in subway stations in Seoul. Build. Environ. 2016, 104, 221-231. [CrossRef]

49. Li, Y.; Yuan, Y.; Li, C.; Han, X.; Zhang, X. Human responses to high air temperature, relative humidity and carbon dioxide concentration in underground refuge chamber. Build. Environ. 2018, 131, 53-62. [CrossRef]

50. Reinikainen, L.M.; Aunela-Tapola, L.; Jaakkola, J.J. Humidification and perceived indoor air quality in the office environment. Occup. Environ. Med. 1997, 54, 322-327. [CrossRef]

51. Reinikainen, L.M.; Jaakkola, J.J. Effects of temperature and humidification in the office environment. Arch. Environ. Health 2001, 56, 365-368. [CrossRef]

52. Reinikainen, L.M.; Jaakkola, J.J.; Seppänen, O. The effect of air humidification on symptoms and perception of indoor air quality in office workers: A six-period cross-over trial. Arch. Environ. Health 1992, 47, 8-15. [CrossRef]

53. Reinikainen, L.M.; Jaakkola, J.J.K. Significance of humidity and temperature on skin and upper airway symptoms. Indoor Air 2003, 13, 344-352. [CrossRef] [PubMed]

54. Fang, L.; Clausen, G.; Fanger, P.O. Impact of Temperature and Humidity on the Perception of Indoor Air Quality. Indoor Air 1998, 8, 80-90. [CrossRef]

55. Jung, A.; Schuppe, H.-C. Influence of genital heat stress on semen quality in humans. Andrologia 2007, 39, 203-215. [CrossRef] [PubMed]

56. Wang, H.-N.; Chen, W.; Wang, Y.; Zhang, Y.; Yang, F.; Xu, S.-P.; Yuan, Y.-H.; Li, H.-P.; Shi, J.-L. Relationship between Type of Neuromuscular Fatigue and PAP after Prolonged Exercise in the High Temperature and High Humidity Environment. China Sport Sci. Technol. 2018, 54, 83-89.

57. Derby, M.M.; Hamehkasi, M.; Eckels, S.; Hwang, G.M.; Jones, B.; Maghirang, R.; Shulan, D. Update of the scientific evidence for specifying lower limit relative humidity levels for comfort, health, and indoor environmental quality in occupied spaces (RP-1630). Sci. Technol. Built Environ. 2017, 23, 30-45. [CrossRef]

58. Wolkoff, P. Indoor air humidity, air quality, and health-An overview. Int. J. Hyg. Environ. Health 2018, 221, 376-390. [CrossRef]

59. Davis, R.E.; McGregor, G.R.; Enfield, K.B. Humidity: A review and primer on atmospheric moisture and human health. Environ. Res. 2016, 144, 106-116. [CrossRef]

60. Han, Y.; Hu, Y.; Qian, F. Effects of air temperature and humidity on particle deposition. Chem. Eng. Res. Des. 2011, 89, 2063-2069. [CrossRef]

61. Qian, J.; Peccia, J.; Ferro, A.R. Walking-induced particle resuspension in indoor environments. Atmos. Environ. 2014, 89, 464-481. [CrossRef] 
62. WHO Regional Office for Europe. WHO Guidelines for Indoor Air Quality: Dampness and Mould; WHO Regional Office for Europe: Geneva, Switzerland, 2009; ISBN 9789289041683.

63. Alves, C.; Duarte, M.; Ferreira, M.; Alves, A.; Almeida, A.; Cunha, Â. Air quality in a school with dampness and mould problems. Air Qual. Atmos. Health 2016, 9, 107-115. [CrossRef]

64. Qian, H.; Zheng, X.; Zhang, M.; Weschler, L.; Sundell, J. Associations between Parents' Perceived Air Quality in Homes and Health among Children in Nanjing, China. PLoS ONE 2016, 11, e0155742. [CrossRef] [PubMed]

65. Sun, Y.; Zhang, Y.; Sundell, J.; Fan, Z.; Bao, L. Dampness in dorm rooms and its associations with allergy and airways infections among college students in China: A cross-sectional study. Indoor Air 2009, 19, 348-356. [CrossRef] [PubMed]

66. Wolkoff, P. External eye symptoms in indoor environments. Indoor Air 2017, 27, 246-260. [CrossRef] [PubMed]

67. Williams, R.; Rankin, N.; Smith, T.; Galler, D.; Seakins, P. Relationship between the humidity and temperature of inspired gas and the function of the airway mucosa. Crit. Care Med. 1996, 24, 1920-1929. [CrossRef] [PubMed]

68. Naclerio, R.M.; Pinto, J.; Assanasen, P.; Baroody, F.M. Observations on the ability of the nose to warm and humidify inspired air. Rhinology 2007, 45, 102-111. [PubMed]

69. Davis, R.E.; Dougherty, E.; McArthur, C.; Huang, Q.S.; Baker, M.G. Cold, dry air is associated with influenza and pneumonia mortality in Auckland, New Zealand. Influenza Other Respir. Viruses 2016, 10, 310-313. [CrossRef] [PubMed]

70. Ikäheimo, T.M.; Jaakkola, K.; Jokelainen, J.; Saukkoriipi, A.; Roivainen, M.; Juvonen, R.; Vainio, O.; Jaakkola, J.J.K. A Decrease in Temperature and Humidity Precedes Human Rhinovirus Infections in a Cold Climate. Viruses 2016, 8, 244. [CrossRef]

71. Morawska, L. Droplet fate in indoor environments, or can we prevent the spread of infection? Indoor Air 2006, 16, 335-347. [CrossRef]

72. Weber, T.P.; Stilianakis, N.I. Inactivation of influenza a viruses in the environment and modes of transmission: A critical review. J. Infect. 2008, 57, 361-373. [CrossRef]

73. ISO. ISO 7730: 2005 Ergonomics of the Thermal Environment. Analytical Determination and Interpretation of Thermal Comfort Using Calculation of the PMV and PPD Indices and Local Thermal Comfort Criteria 2005. Available online: https://www.iso.org/standard/39155.html (accessed on 7 February 2020).

74. Frontczak, M.; Wargocki, P. Literature survey on how different factors influence human comfort in indoor environments. Build. Environ. 2011, 46, 922-937. [CrossRef]

75. Rodriguez, C.M.; D'Alessandro, M. Indoor thermal comfort review: The tropics as the next frontier. Urban. Clim. 2019, 29, 100488. [CrossRef]

76. Li, W.; Zhang, G.; Ji, L. Healthy Building Indoor Thermal Comfort Simulation and Analysis Method. Green Build. 2019, 1, 51-55.

77. Zhao, K.; Liu, X.-H.; Zhang, T.; Jiang, Y. Performance of temperature and humidity independent control air-conditioning system in an office building. Energy Build. 2011, 43, 1895-1903. [CrossRef]

78. Yi, X. Application of temperature and humidity independent control air conditioning system to underground railway stations. Heat. Vent. Air Cond. 2010, 40, 19-21.

79. Nieuwenhuijsen, M.J.; Gómez-Perales, J.E.; Colvile, R.N. Levels of particulate air pollution, its elemental composition, determinants and health effects in metro systems. Atmos. Environ. 2007, 41, 7995-8006. [CrossRef]

80. Moreno, T.; Martins, V.; Reche, C.; Minguillón, M.C.; de Miguel, E.; Querol, X. Air Quality in Subway Systems. In Non-Exhaust Emissions; Elsevier: Amsterdam, The Netherlands, 2018; pp. 289-321. ISBN 9780128117705.

81. Chen, Y.-Y.; Sung, F.-C.; Chen, M.-L.; Mao, I.-F.; Lu, C.-Y. Indoor Air Quality in the Metro System in North Taiwan. Int. J. Environ. Res. Public Health 2016, 13, 1200. [CrossRef]

82. Hwang, S.H.; Park, W.M. Indoor air quality assessment with respect to culturable airborne bacteria, total volatile organic compounds, formaldehyde, $\mathrm{PM}_{10}, \mathrm{CO}_{2}, \mathrm{NO}_{2}$, and $\mathrm{O}_{3}$ in underground subway stations and parking lots. Air Qual. Atmos. Health 2019, 12, 435-441. [CrossRef]

83. Martins, V.; Cruz Minguillón, M.; Moreno, T.; Querol, X.; de Miguel, E.; Capdevila, M.; Centelles, S.; Lazaridis, M. Deposition of aerosol particles from a subway microenvironment in the human respiratory tract. J. Aerosol Sci. 2015, 90, 103-113. [CrossRef] 
84. Adams, H.S.; Nieuwenhuijsen, M.J.; Colvile, R.N.; McMullen, M.A.S.; Khandelwal, P. Fine particle (PM2.5) personal exposure levels in transport microenvironments, London, UK. Sci. Total Environ. 2001, 279, $29-44$. [CrossRef]

85. Furuya, K.; Kudo, Y.; Okinaga, K.; Yamuki, M.; Takahashi, S.; Araki, Y.; Hisamatsu, Y. Seasonal variation and their characterization of suspended particulate matter in the air of subway stations. J. Trace Microprobe Tech. 2001, 19, 469-485. [CrossRef]

86. Salma, I. Chapter 4. Air Pollution in Underground Railway Systems. In Air Quality in Urban Environments; Harrison, R.M., Hester, R.E., Eds.; Royal Society of Chemistry: Cambridge, UK, 2009; pp. 65-84. ISBN 978-1-84755-907-4.

87. Querol, X.; Moreno, T.; Karanasiou, A.; Reche, C.; Alastuey, A.; Viana, M.; Font, O.; Gil, J.; de Miguel, E.; Capdevila, M. Variability of levels and composition of $\mathrm{PM}_{10}$ and $\mathrm{PM}_{2.5}$ in the Barcelona metro system. Atmos. Chem. Phys. 2012, 12, 5055-5076. [CrossRef]

88. Johansson, C.; Johansson, P.-Å. Particulate matter in the underground of Stockholm. Atmos. Environ. 2003, 37, 3-9. [CrossRef]

89. Kim, K.Y.; Kim, Y.S.; Roh, Y.M.; Lee, C.M.; Kim, C.N. Spatial distribution of particulate matter (PM10 and PM2.5) in Seoul Metropolitan Subway stations. J. Hazard. Mater. 2008, 154, 440-443. [CrossRef]

90. Loxham, M.; Cooper, M.J.; Gerlofs-Nijland, M.E.; Cassee, F.R.; Davies, D.E.; Palmer, M.R.; Teagle, D.A.H. Physicochemical characterization of airborne particulate matter at a mainline underground railway station. Environ. Sci. Technol. 2013, 47, 3614-3622. [CrossRef]

91. Moreno, T.; Pérez, N.; Reche, C.; Martins, V.; de Miguel, E.; Capdevila, M.; Centelles, S.; Minguillón, M.C.; Amato, F.; Alastuey, A.; et al. Subway platform air quality: Assessing the influences of tunnel ventilation, train piston effect and station design. Atmos. Environ. 2014, 92, 461-468. [CrossRef]

92. Park, S.-B.-S.-N.; Lee, T.-J.; Ko, H.-K.; Bae, S.-J.; Kim, S.-D.; Park, D.; Sohn, J.-R.; Kim, D.-S. Identification of PM 10 Chemical Characteristics and Sources and Estimation of their Contributions in a Seoul Metropolitan Subway Station. J. Korean Soc. Atmos. Environ. 2013, 29, 74-85. [CrossRef]

93. Park, D.-U.; Ha, K.-C. Characteristics of PM10, PM2.5, CO2 and CO monitored in interiors and platforms of subway train in Seoul, Korea. Environ. Int. 2008, 34, 629-634. [CrossRef]

94. Perrino, C.; Marcovecchio, F.; Tofful, L.; Canepari, S. Particulate matter concentration and chemical composition in the metro system of Rome, Italy. Environ. Sci. Pollut. Res. Int. 2015, 22, 9204-9214. [CrossRef]

95. Ripanucci, G.; Grana, M.; Vicentini, L.; Magrini, A.; Bergamaschi, A. Dust in the Underground Railway Tunnels of an Italian Town. J. Occup. Environ. Hyg. 2006, 3, 16-25. [CrossRef]

96. Salma, I.; Weidinger, T.; Maenhaut, W. Time-resolved mass concentration, composition and sources of aerosol particles in a metropolitan underground railway station. Atmos. Environ. 2007, 41, 8391-8405. [CrossRef]

97. Salma, I.; Pósfai, M.; Kovács, K.; Kuzmann, E.; Homonnay, Z.; Posta, J. Properties and sources of individual particles and some chemical species in the aerosol of a metropolitan underground railway station. Atmos. Environ. 2009, 43, 3460-3466. [CrossRef]

98. Minguillón, M.C.; Reche, C.; Martins, V.; Amato, F.; de Miguel, E.; Capdevila, M.; Centelles, S.; Querol, X.; Moreno, T. Aerosol sources in subway environments. Environ. Res. 2018, 167, 314-328. [CrossRef] [PubMed]

99. Kam, W.; Delfino, R.J.; Schauer, J.J.; Sioutas, C. A comparative assessment of PM 2.5 exposures in light-rail, subway, freeway, and surface street environments in Los Angeles and estimated lung cancer risk. Environ. Sci.: Process. Impacts 2013, 15, 234-243. [CrossRef]

100. Sundh, J.; Olofsson, U.; Olander, L.; Jansson, A. Wear rate testing in relation to airborne particles generated in a wheel-rail contact. Lubr. Sci. 2009, 21, 135-150. [CrossRef]

101. Zimmer, A.T.; Maynard, A.D. Investigation of the aerosols produced by a high-speed, hand-held grinder using various substrates. Ann. Occup. Hyg. 2002, 46, 663-672. [CrossRef]

102. Park, J.H.; Young Woo, H.; Chuel Park, J. Major factors affecting the aerosol particulate concentration in the underground stations. Indoor Built Environ. 2014, 23, 629-639. [CrossRef]

103. Raut, J.-C.; Chazette, P.; Fortain, A. Link between aerosol optical, microphysical and chemical measurements in an underground railway station in Paris. Atmos. Environ. 2009, 43, 860-868. [CrossRef]

104. Cheng, Y.-H.; Lin, Y.-L.; Liu, C.-C. Levels of PM10 and PM2.5 in Taipei Rapid Transit System. Atmos. Environ. 2008, 42, 7242-7249. [CrossRef]

105. Cheng, Y.-H.; Lin, Y.-L. Measurement of Particle Mass Concentrations and Size Distributions in an Underground Station. Aerosol Air Qual. Res. 2010, 10, 22-29. [CrossRef] 
106. Murruni, L.G.; Solanes, V.; Debray, M.; Kreiner, A.J.; Davidson, J.; Davidson, M.; Vázquez, M.; Ozafrán, M. Concentrations and elemental composition of particulate matter in the Buenos Aires underground system. Atmos. Environ. 2009, 43, 4577-4583. [CrossRef]

107. Mendes, L.; Gini, M.I.; Biskos, G.; Colbeck, I.; Eleftheriadis, K. Airborne ultrafine particles in a naturally ventilated metro station: Dominant sources and mixing state determined by particle size distribution and volatility measurements. Environ. Pollut. 2018, 239, 82-94. [CrossRef] [PubMed]

108. Martins, V.; Moreno, T.; Mendes, L.; Eleftheriadis, K.; Diapouli, E.; Alves, C.A.; Duarte, M.; de Miguel, E.; Capdevila, M.; Querol, X.; et al. Factors controlling air quality in different European subway systems. Environ. Res. 2016, 146, 35-46. [CrossRef] [PubMed]

109. Hwang, S.H.; Park, W.M.; Park, J.B.; Nam, T. Characteristics of PM10 and CO2 concentrations on 100 underground subway station platforms in 2014 and 2015. Atmos. Environ. 2017, 167, 143-149. [CrossRef]

110. Cusack, M.; Talbot, N.; Ondráček, J.; Minguillón, M.C.; Martins, V.; Klouda, K.; Schwarz, J.; Ždímal, V. Variability of aerosols and chemical composition of PM 10, PM 2.5 and PM 1 on a platform of the Prague underground metro. Atmos. Environ. 2015, 118, 176-183. [CrossRef]

111. Kim, B.; Jung, H.-J.; Song, Y.-C.; Lee, M.-J.; Kim, H.; Kim, J.-C.; Sohn, J.; Ro, C.-U. Characterization of Summertime Aerosol Particles Collected at Subway Stations in Seoul, Korea Using Low-Z Particle Electron Probe X-ray Microanalysis. AJAE 2010, 4, 97-105. [CrossRef]

112. Kam, W.; Ning, Z.; Shafer, M.M.; Schauer, J.J.; Sioutas, C. Chemical characterization and redox potential of coarse and fine particulate matter (PM) in underground and ground-level rail systems of the Los Angeles Metro. Environ. Sci. Technol. 2011, 45, 6769-6776. [CrossRef]

113. Chow, J.C.; Watson, J.G.; Edgerton, S.A.; Vega, E. Chemical composition of PM2.5 and PM10 in Mexico City during winter 1997. Sci. Total Environ. 2002, 287, 177-201. [CrossRef]

114. Aarnio, P.; Yli-Tuomi, T.; Kousa, A.; Mäkelä, T.; Hirsikko, A.; Hämeri, K.; Räisänen, M.; Hillamo, R.; Koskentalo, T.; Jantunen, M. The concentrations and composition of and exposure to fine particles (PM2.5) in the Helsinki subway system. Atmos. Environ. 2005, 39, 5059-5066. [CrossRef]

115. Braniš, M. The contribution of ambient sources to particulate pollution in spaces and trains of the Prague underground transport system. Atmos. Environ. 2006, 40, 348-356. [CrossRef]

116. Cui, G.; Zhou, L.; Dearing, J. Granulometric and magnetic properties of deposited particles in the Beijing subway and the implications for air quality management. Sci. Total Environ. 2016, 568, 1059-1068. [CrossRef]

117. Eom, H.-J.; Jung, H.-J.; Sobanska, S.; Chung, S.-G.; Son, Y.-S.; Kim, J.-C.; Sunwoo, Y.; Ro, C.-U. Iron speciation of airborne subway particles by the combined use of energy dispersive electron probe $\mathrm{X}$-ray microanalysis and Raman microspectrometry. Anal. Chem. 2013, 85, 10424-10431. [CrossRef] [PubMed]

118. Guo, L.; Hu, Y.; Hu, Q.; Lin, J.; Li, C.; Chen, J.; Li, L.; Fu, H. Characteristics and chemical compositions of particulate matter collected at the selected metro stations of Shanghai, China. Sci. Total Environ. 2014, 496, 443-452. [CrossRef] [PubMed]

119. Jung, H.-J.; Kim, B.; Ryu, J.; Maskey, S.; Kim, J.-C.; Sohn, J.; Ro, C.-U. Source identification of particulate matter collected at underground subway stations in Seoul, Korea using quantitative single-particle analysis. Atmos. Environ. 2010, 44, 2287-2293. [CrossRef]

120. Jung, H.-J.; Kim, B.; Malek, M.A.; Koo, Y.S.; Jung, J.H.; Son, Y.-S.; Kim, J.-C.; Kim, H.; Ro, C.-U. Chemical speciation of size-segregated floor dusts and airborne magnetic particles collected at underground subway stations in Seoul, Korea. J. Hazard. Mater. 2012, 213-214, 331-340. [CrossRef]

121. Kang, S.; Hwang, H.; Park, Y.; Kim, H.; Ro, C.-U. Chemical compositions of subway particles in Seoul, Korea determined by a quantitative single particle analysis. Environ. Sci. Technol. 2008, 42, 9051-9057. [CrossRef]

122. Lu, S.; Liu, D.; Zhang, W.; Liu, P.; Fei, Y.; Gu, Y.; Wu, M.; Yu, S.; Yonemochi, S.; Wang, X.; et al. Physico-chemical characterization of PM2.5 in the microenvironment of Shanghai subway. Atmos. Res. 2015, 153, 543-552. [CrossRef]

123. Martins, V.; Moreno, T.; Minguillón, M.C.; van Drooge, B.L.; Reche, C.; Amato, F.; de Miguel, E.; Capdevila, M.; Centelles, S.; Querol, X. Origin of inorganic and organic components of PM2.5 in subway stations of Barcelona, Spain. Environ. Pollut. 2016, 208, 125-136. [CrossRef]

124. Moreno, T.; Martins, V.; Querol, X.; Jones, T.; BéruBé, K.; Minguillón, M.C.; Amato, F.; Capdevila, M.; de Miguel, E.; Centelles, S.; et al. A new look at inhalable metalliferous airborne particles on rail subway platforms. Sci. Total Environ. 2015, 505, 367-375. [CrossRef] 
125. Font, O.; Moreno, T.; Querol, X.; Martins, V.; Sánchez Rodas, D.; de Miguel, E.; Capdevila, M. Origin and speciation of major and trace PM elements in the barcelona subway system. Transp. Res. Part D Transp. Environ. 2019, 72, 17-35. [CrossRef]

126. Martins, V.; Minguillón, M.C.; Moreno, T.; Mendes, L.; Eleftheriadis, K.; Alves, C.A.; de Miguel, E.; Querol, X. Characterisation of Airborne Particulate Matter in Different European Subway Systems. In Urban Transport Systems; Yaghoubi, H., Ed.; InTech: Vienna, Austria, 2017; ISBN 978-953-51-2873-1.

127. Mugica-Álvarez, V.; Figueroa-Lara, J.; Romero-Romo, M.; Sepúlveda-Sánchez, J.; López-Moreno, T. Concentrations and properties of airborne particles in the Mexico City subway system. Atmos. Environ. 2012, 49, 284-293. [CrossRef]

128. Moreno, T.; Querol, X.; Martins, V.; Minguillón, M.C.; Reche, C.; Ku, L.H.; Eun, H.R.; Ahn, K.H.; Capdevila, M.; de Miguel, E. Formation and alteration of airborne particles in the subway environment. Environ. Sci. Process. Impacts 2017, 19, 59-64. [CrossRef] [PubMed]

129. Park, D.; Lee, T.; Hwang, D.; Jung, W.; Lee, Y.; Cho, K.; Kim, D.; Lee, K. Identification of the sources of PM 10 in a subway tunnel using positive matrix factorization. J. Air Waste Manag. Assoc. 2014, 64, 1361-1368. [CrossRef] [PubMed]

130. Zhang, W.; Jiang, H.; Dong, C.; Yan, Q.; Yu, L.; Yu, Y. Magnetic and geochemical characterization of iron pollution in subway dusts in Shanghai, China. Geochem. Geophys. Geosyst. 2011, 12. [CrossRef]

131. Sitzmann, B.; Kendall, M.; Watt, J.; Williams, I. Characterisation of airborne particles in London by computer-controlled scanning electron microscopy. Sci. Total Environ. 1999, 241, 63-73. [CrossRef]

132. Minguillón, M.C. Air Quality in Subway Systems: Particulate Matter Concentrations, Chemical Composition, Sources and Personal Exposure; Universitat de Barcelona: Barcelona, Spain, 2016.

133. van Ryswyk, K.; Anastasopolos, A.T.; Evans, G.; Sun, L.; Sabaliauskas, K.; Kulka, R.; Wallace, L.; Weichenthal, S. Metro Commuter Exposures to Particulate Air Pollution and PM2.5-Associated Elements in Three Canadian Cities: The Urban Transportation Exposure Study. Environ. Sci. Technol. 2017, 51, 5713-5720. [CrossRef]

134. Şahin, Ü.A.; Onat, B.; Stakeeva, B.; Ceran, T.; Karim, P. PM10 concentrations and the size distribution of Cu and Fe-containing particles in Istanbul's subway system. Transp. Res. Part D Transp. Environ. 2012, 17, 48-53. [CrossRef]

135. Qiao, T.; Xiu, G.; Zheng, Y.; Yang, J.; Wang, L.; Yang, J.; Huang, Z. Preliminary investigation of PM1, PM2.5, PM10 and its metal elemental composition in tunnels at a subway station in Shanghai, China. Transp. Res. Part D Transp. Environ. 2015, 41, 136-146. [CrossRef]

136. Byeon, S.-H.; Willis, R.; Peters, T.M. Chemical characterization of outdoor and subway fine (PM(2.5-1.0)) and coarse (PM(10-2.5)) particulate matter in Seoul (Korea) by computer-controlled scanning electron microscopy (CCSEM). Int. J. Environ. Res. Public Health 2015, 12, 2090-2104. [CrossRef]

137. Lee, Y.; Lee, Y.-C.; Kim, T.; Choi, J.S.; Park, D. Sources and Characteristics of Particulate Matter in Subway Tunnels in Seoul, Korea. Int. J. Environ. Res. Public Health 2018, 15, 2534. [CrossRef]

138. Gómez-Perales, J.E.; Colvile, R.N.; Nieuwenhuijsen, M.J.; Fernández-Bremauntz, A.; Gutiérrez-Avedoy, V.J.; Páramo-Figueroa, V.H.; Blanco-Jiménez, S.; Bueno-López, E.; Mandujano, F.; Bernabé-Cabanillas, R.; et al. Commuters' exposure to PM2.5, CO, and benzene in public transport in the metropolitan area of Mexico City. Atmos. Environ. 2004, 38, 1219-1229. [CrossRef]

139. van Drooge, B.L.; Prats, R.M.; Reche, C.; Minguillón, M.; Querol, X.; Grimalt, J.O.; Moreno, T. Origin of polycyclic aromatic hydrocarbons and other organic pollutants in the air particles of subway stations in Barcelona. Sci. Total Environ. 2018, 642, 148-154. [CrossRef] [PubMed]

140. Choi, S.; Park, J.-H.; Kim, S.-Y.; Kwak, H.; Kim, D.; Lee, K.-H.; Park, D.-U. Characteristics of PM2.5 and Black Carbon Exposure among Subway Workers. Int. J. Environ. Res. Public Health 2019, 16, 2901. [CrossRef] [PubMed]

141. Liu, Y.; Lan, B.; Shirai, J.; Austin, E.; Yang, C.; Seto, E. Exposures to Air Pollution and Noise from Multi-Modal Commuting in a Chinese City. Int. J. Environ. Res. Public Health 2019, 16, 2539. [CrossRef]

142. Thomas, R.J.; Webber, D.; Sellors, W.; Collinge, A.; Frost, A.; Stagg, A.J.; Bailey, S.C.; Jayasekera, P.N.; Taylor, R.R.; Eley, S.; et al. Characterization and deposition of respirable large- and small-particle bioaerosols. Appl. Environ. Microbiol. 2008, 74, 6437-6443. [CrossRef]

143. Kim, M.; Park, S.; Namgung, H.-G.; Kwon, S.-B. Estimation of inhaled airborne particle number concentration by subway users in Seoul, Korea. Environ. Pollut. 2017, 231, 663-670. [CrossRef] 
144. Kam, W.; Cheung, K.; Daher, N.; Sioutas, C. Particulate matter (PM) concentrations in underground and ground-level rail systems of the Los Angeles Metro. Atmos. Environ. 2011, 45, 1506-1516. [CrossRef]

145. Abbasi, S.; Jansson, A.; Sellgren, U.; Olofsson, U. Particle Emissions from Rail Traffic: A Literature Review. Crit. Rev. Environ. Sci. Technol. 2013, 43, 2511-2544. [CrossRef]

146. Colombi, C.; Angius, S.; Gianelle, V.; Lazzarini, M. Particulate matter concentrations, physical characteristics and elemental composition in the Milan underground transport system. Atmos. Environ. 2013, 70, 166-178. [CrossRef]

147. Wang, X.; Oliver Gao, H. Exposure to fine particle mass and number concentrations in urban transportation environments of New York City. Trans. Res. Part D Trans. Environ. 2011, 16, 384-391. [CrossRef]

148. Liu, Q.; Yu, X.; Shi, G. Test and Analysis on Air Particulate Matter Concentration of a Subway Station in Chongqing. Procedia Eng. 2017, 205, 856-862. [CrossRef]

149. Guo, E.; Shen, H.; He, L.; Zhang, J. Investigation of air pollution of Shanghai subway stations in ventilation seasons in terms of PM2.5 and PM10. Toxicol. Ind. Health 2017, 33, 588-600. [CrossRef]

150. Zhang, Y.; Chu, M.; Zhang, J.; Duan, J.; Hu, D.; Zhang, W.; Yang, X.; Jia, X.; Deng, F.; Sun, Z. Urine metabolites associated with cardiovascular effects from exposure of size-fractioned particulate matter in a subway environment: A randomized crossover study. Environ. Int. 2019, 130, 104920. [CrossRef]

151. Cho, C.-C.; Hsieh, W.-Y.; Tsai, C.-H.; Chen, C.-Y.; Chang, H.-F.; Lin, C.-S. In Vitro and In Vivo Experimental Studies of PM2.5 on Disease Progression. Int. J. Environ. Res. Public Health 2018, 15, 1380. [CrossRef]

152. Bachoual, R.; Boczkowski, J.; Goven, D.; Amara, N.; Tabet, L.; On, D.; Leçon-Malas, V.; Aubier, M.; Lanone, S. Biological effects of particles from the paris subway system. Chem. Res. Toxicol. 2007, 20, 1426-1433. [CrossRef] [PubMed]

153. Bigert, C.; Alderling, M.; Svartengren, M.; Plato, N.; de Faire, U.; Gustavsson, P. Blood markers of inflammation and coagulation and exposure to airborne particles in employees in the Stockholm underground. Occup. Environ. Med. 2008, 65, 655-658. [CrossRef]

154. Chillrud, S.N.; Epstein, D.; Ross, J.M.; Sax, S.N.; Pederson, D.; Spengler, J.D.; Kinney, P.L. Elevated airborne exposures of teenagers to manganese, chromium, and iron from steel dust and New York City's subway system. Environ. Sci. Technol. 2004, 38, 732-737. [CrossRef]

155. Grass, D.S.; Ross, J.M.; Family, F.; Barbour, J.; James Simpson, H.; Coulibaly, D.; Hernandez, J.; Chen, Y.; Slavkovich, V.; Li, Y.; et al. Airborne particulate metals in the New York City subway: A pilot study to assess the potential for health impacts. Environ. Res. 2010, 110, 1-11. [CrossRef]

156. Janssen, N.A.H.; Yang, A.; Strak, M.; Steenhof, M.; Hellack, B.; Gerlofs-Nijland, M.E.; Kuhlbusch, T.; Kelly, F.; Harrison, R.; Brunekreef, B.; et al. Oxidative potential of particulate matter collected at sites with different source characteristics. Sci. Total Environ. 2014, 472, 572-581. [CrossRef]

157. Karlsson, H.L.; Holgersson, A.; Möller, L. Mechanisms related to the genotoxicity of particles in the subway and from other sources. Chem. Res. Toxicol. 2008, 21, 726-731. [CrossRef]

158. Karlsson, H.L.; Ljungman, A.G.; Lindbom, J.; Möller, L. Comparison of genotoxic and inflammatory effects of particles generated by wood combustion, a road simulator and collected from street and subway. Toxicol. Lett. 2006, 165, 203-211. [CrossRef]

159. Karlsson, H.L.; Nilsson, L.; Möller, L. Subway particles are more genotoxic than street particles and induce oxidative stress in cultured human lung cells. Chem. Res. Toxicol. 2005, 18, 19-23. [CrossRef] [PubMed]

160. Moreno, T.; Kelly, F.J.; Dunster, C.; Oliete, A.; Martins, V.; Reche, C.; Minguillón, M.C.; Amato, F.; Capdevila, M.; de Miguel, E.; et al. Oxidative potential of subway PM 2.5. Atmos. Environ. 2017, 148, 230-238. [CrossRef]

161. Seaton, A.; Cherrie, J.; Dennekamp, M.; Donaldson, K.; Hurley, J.F.; Tran, C.L. The London Underground: Dust and hazards to health. Occup. Environ. Med. 2005, 62, 355-362. [CrossRef] [PubMed]

162. Spagnolo, A.; Ottria, G.; Perdelli, F.; Cristina, M. Chemical Characterisation of the Coarse and Fine Particulate Matter in the Environment of an Underground Railway System: Cytotoxic Effects and Oxidative Stress-A Preliminary Study. Int. J. Environ. Res. Public Health 2015, 12, 4031-4046. [CrossRef]

163. Steenhof, M.; Gosens, I.; Strak, M.; Godri, K.J.; Hoek, G.; Cassee, F.R.; Mudway, I.S.; Kelly, F.J.; Harrison, R.M.; Lebret, E.; et al. In vitro toxicity of particulate matter (PM) collected at different sites in the Netherlands is associated with PM composition, size fraction and oxidative potential-The RAPTES project. Part Fibre Toxicol. 2011, 8, 26. [CrossRef] 
164. Jung, M.H.; Kim, H.R.; Park, Y.J.; Park, D.S.; Chung, K.H.; Oh, S.M. Genotoxic effects and oxidative stress induced by organic extracts of particulate matter (PM10) collected from a subway tunnel in Seoul, Korea. Mutat. Res./Genet. Toxicol. Environ. Mutagenesis 2012, 749, 39-47. [CrossRef]

165. Chillrud, S.N.; Grass, D.; Ross, J.M.; Coulibaly, D.; Slavkovich, V.; Epstein, D.; Sax, S.N.; Pederson, D.; Johnson, D.; Spengler, J.D.; et al. Steel dust in the New York City subway system as a source of manganese, chromium, and iron exposures for transit workers. J. Urban. Health 2005, 82, 33-42. [CrossRef]

166. Lovett, C.; Shirmohammadi, F.; Sowlat, M.H.; Sioutas, C. Commuting in Los Angeles: Cancer and Non-cancer Health Risks of Roadway, Light-Rail and Subway Transit Routes. Aerosol Air Qual. Res. 2018, 18, 2363-2374. [CrossRef]

167. Khunashvili, N.; Tsimakuridze, M.; Bakradze, L.; Khachapuridze, N.; Tsimakuridze, M. Working conditions and state of health of Tbilisi subway employees. Georgian Med. News 2017, 143-147.

168. Klepczyńska Nyström, A.; Svartengren, M.; Grunewald, J.; Pousette, C.; Rödin, I.; Lundin, A.; Sköld, C.M.; Eklund, A.; Larsson, B.-M. Health effects of a subway environment in healthy volunteers. Eur. Respir. J. 2010, 36, 240-248. [CrossRef]

169. Chan, C.-C.; Spengler, J.D.; Özkaynak, H.; Lefkopoulou, M. Commuter Exposures to VOCs in Boston, Massachusetts. J. Air Waste Manag. Assoc. 1991, 41, 1594-1600. [CrossRef] [PubMed]

170. Feng, Y.; Mu, C.; Zhai, J.; Li, J.; Zou, T. Characteristics and personal exposures of carbonyl compounds in the subway stations and in-subway trains of Shanghai, China. J. Hazard. Mater. 2010, 183, 574-582. [CrossRef] [PubMed]

171. Dor, F.; Le Moullec, Y.; Festy, B. Exposure of City Residents to Carbon Monoxide and Monocyclic Aromatic Hydrocarbons during Commuting Trips in the Paris Metropolitan Area. J. Air Waste Manag. Assoc. 1995, 45, 103-110. [CrossRef]

172. Fromme, H.; Oddoy, A.; PILOTY, M.; KRAUSE, M.; LAHRZ, T. Polycyclic aromatic hydrocarbons (PAH) and diesel engine emission (elemental carbon) inside a car and a subway train. Sci. Total Environ. 1998, 217, 165-173. [CrossRef]

173. Shiohara, N.; Fernández-Bremauntz, A.A.; Blanco Jiménez, S.; Yanagisawa, Y. The commuters' exposure to volatile chemicals and carcinogenic risk in Mexico City. Atmos. Environ. 2005, 39, 3481-3489. [CrossRef]

174. Zhang, Y.; Li, C.; Wang, X.; Guo, H.; Feng, Y.; Chen, J. Rush-hour aromatic and chlorinated hydrocarbons in selected subway stations of Shanghai, China. J. Environ. Sci. 2012, 24, 131-141. [CrossRef]

175. Fujii, R.K.; Oyola, P.; Pereira, J.C.R.; Nedel, A.S.; Cacavallo, R.C. Air pollution levels in two São Paulo subway stations. In Highway and Urban Environment: Proceedings of the 8th Highway and Urban Environment Symposiumh; Morrison, G.M., Rauch, S., Eds.; Springer: Dordrecht, The Netherlands, 2007; pp. 181-190. ISBN 978-1-4020-6009-0.

176. Chan, L.Y.; Lau, W.L.; Wang, X.M.; Tang, J.H. Preliminary measurements of aromatic VOCs in public transportation modes in Guangzhou, China. Environ. Int. 2003, 29, 429-435. [CrossRef]

177. Lau, W.-L.; Chan, L.-Y. Commuter exposure to aromatic VOCs in public transportation modes in Hong Kong. Sci. Total Environ. 2003, 308, 143-155. [CrossRef]

178. Li, J.; Yan, L.; Xie, C.; Cai, J.; Liu, W. Characteristics of Carbonyls: Concentrations, Possible Sources, and Personal Exposures for Indoor and Outdoor Subway Microenvironments. In Proceedings of the 2012 2nd International Conference on Remote Sensing, Environment and Transportation Engineering (RSETE), Nanjing, Jiangsu, China, 1-3 June 2012; IEEE: Piscataway, NJ, USA, 2012; pp. 1-5.

179. Gong, Y.; Wei, Y.; Cheng, J.; Jiang, T.; Chen, L.; Xu, B. Health risk assessment and personal exposure to Volatile Organic Compounds (VOCs) in metro carriages-A case study in Shanghai, China. Sci. Total Environ. 2017, 574, 1432-1438. [CrossRef]

180. Midander, K.; Elihn, K.; Wallén, A.; Belova, L.; Karlsson, A.-K.B.; Wallinder, I.O. Characterisation of nanoand micron-sized airborne and collected subway particles, a multi-analytical approach. Sci. Total Environ. 2012, 427-428, 390-400. [CrossRef]

181. Possanzini, M.; Di Palo, V.; Brancaleoni, E.; Frattoni, M.; Ciccioli, P. A train of carbon and DNPH-coated cartridges for the determination of carbonyls from $\mathrm{C} 1$ to $\mathrm{C} 12$ in air and emission samples. Atmos. Environ. 2000, 34, 5311-5318. [CrossRef]

182. Park, W.M.; Park, J.B.; Roh, J.; Hwang, S.H. Levels of formaldehyde and TVOCs and influential factors of 100 underground station environments from 2013 to 2015. Hum. Ecol. Risk Assess. Int. J. 2018, 24, 1030-1042. [CrossRef] 
183. Yan, C.; Zheng, M.; Yang, Q.; Zhang, Q.; Qiu, X.; Zhang, Y.; Fu, H.; Li, X.; Zhu, T.; Zhu, Y. Commuter exposure to particulate matter and particle-bound PAHs in three transportation modes in Beijing, China. Environ. Pollut. 2015, 204, 199-206. [CrossRef] [PubMed]

184. Zhao, L.; Wang, X.; He, Q.; Wang, H.; Sheng, G.; Chan, L.Y.; Fu, J.; Blake, D.R. Exposure to hazardous volatile organic compounds, PM10 and CO while walking along streets in urban Guangzhou, China. Atmos. Environ. 2004, 38, 6177-6184. [CrossRef]

185. Xu, H.; Zhang, Q.; Song, N.; Guo, M.; Zhang, S.; Ji, G.; Shi, L. Personal exposure and health risk assessment of carbonyls in family cars and public transports-a comparative study in Nanjing, China. Environ. Sci. Pollut. Res. Int. 2017, 24, 26111-26119. [CrossRef] [PubMed]

186. Tagiyeva, N.; Sheikh, A. Domestic exposure to volatile organic compounds in relation to asthma and allergy in children and adults. Expert Rev. Clin. Immunol. 2014, 10, 1611-1639. [CrossRef]

187. Odum, J.R.; Jungkamp, T.P.W.; Griffin, R.J.; Forstner, H.J.L.; Flagan, R.C.; Seinfeld, J.H. Aromatics, Reformulated Gasoline, and Atmospheric Organic Aerosol Formation. Environ. Sci. Technol. 1997, 31, 1890-1897. [CrossRef]

188. Bergvall, C.; Westerholm, R. Identification and determination of highly carcinogenic dibenzopyrene isomers in air particulate samples from a street canyon, a rooftop, and a subway station in Stockholm. Environ. Sci. Technol. 2007, 41, 731-737. [CrossRef]

189. Nielsen, G.D.; Larsen, S.T.; Wolkoff, P. Re-evaluation of the WHO (2010) formaldehyde indoor air quality guideline for cancer risk assessment. Arch. Toxicol. 2017, 91, 35-61. [CrossRef]

190. Leung, M.H.Y.; Wilkins, D.; Li, E.K.T.; Kong, F.K.F.; Lee, P.K.H. Indoor-air microbiome in an urban subway network: Diversity and dynamics. Appl. Environ. Microbiol. 2014, 80, 6760-6770. [CrossRef]

191. Zhou, F.; Wang, Y. Characteristics of antibiotic resistance of airborne Staphylococcus isolated from metro stations. Int. J. Environ. Res. Public Health 2013, 10, 2412-2426. [CrossRef] [PubMed]

192. Cho, J.H.; Hee Min, K.; Paik, N.W. Temporal variation of airborne fungi concentrations and related factors in subway stations in Seoul, Korea. Int. J. Hyg. Environ. Health 2006, 209, 249-255. [CrossRef] [PubMed]

193. Zhou, F.; Wang, Y. Detection of airborne bacteria and mildew in the Shanghai metro system. Int. J. Med. Health Biomed. Bioeng. Pharm. Eng. 2012, 6, 1213-1216.

194. Hwang, S.H.; Jang, S.; Park, W.M.; Park, J.B. Concentrations and identification of culturable airborne fungi in underground stations of the Seoul metro. Environ. Sci. Pollut. Res. Int. 2016, 23, 20680-20686. [CrossRef]

195. Triadó-Margarit, X.; Veillette, M.; Duchaine, C.; Talbot, M.; Amato, F.; Minguillón, M.C.; Martins, V.; de Miguel, E.; Casamayor, E.O.; Moreno, T. Bioaerosols in the Barcelona subway system. Indoor Air 2017, 27, 564-575. [CrossRef]

196. Hernández-Castillo, O.; Mugica-Álvarez, V.; Castañeda-Briones, M.T.; Murcia, J.M.; García-Franco, F.; Falcón Briseño, Y. Aerobiological study in the Mexico City subway system. Aerobiologia 2014, 30, 357-367. [CrossRef]

197. Dybwad, M.; Granum, P.E.; Bruheim, P.; Blatny, J.M. Characterization of airborne bacteria at an underground subway station. Appl. Environ. Microbiol. 2012, 78, 1917-1929. [CrossRef]

198. Hwang, S.H.; Park, J.B. Comparison of culturable airborne bacteria and related environmental factors at underground subway stations between 2006 and 2013. Atmos. Environ. 2014, 84, 289-293. [CrossRef]

199. Kim, K.Y.; Kim, Y.S.; Kim, D.; Kim, H.T. Exposure level and distribution characteristics of airborne bacteria and fungi in Seoul metropolitan subway stations. Ind. Health 2011, 49, 242-248. [CrossRef]

200. Dybwad, M.; Skogan, G.; Blatny, J.M. Temporal variability of the bioaerosol background at a subway station: Concentration level, size distribution, and diversity of airborne bacteria. Appl. Environ. Microbiol. 2014, 80, 257-270. [CrossRef]

201. Robertson, C.E.; Baumgartner, L.K.; Harris, J.K.; Peterson, K.L.; Stevens, M.J.; Frank, D.N.; Pace, N.R. Culture-independent analysis of aerosol microbiology in a metropolitan subway system. Appl. Environ. Microbiol. 2013, 79, 3485-3493. [CrossRef] [PubMed]

202. Bogomolova, E.; Kirtsideli, I. Airborne fungi in four stations of the St. Petersburg Underground railway system. Int. Biodeterior. Biodegrad. 2009, 63, 156-160. [CrossRef]

203. Moustafa, K. Eating in public transportation: A behavior to avoid for health and sanitary purposes? Presse Med. 2018, 47, 606-610. [CrossRef] [PubMed]

204. Fan, H.; Li, X.; Deng, J.; Da, G.; Gehin, E.; Yao, M. Time-Dependent Size-Resolved Bacterial and Fungal Aerosols in Beijing Subway. Aerosol Air Qual. Res. 2017, 17, 799-809. [CrossRef] 
205. Picco, A.M.; Rodolfi, M. Airborne fungi as biocontaminants at two Milan underground stations. Int. Biodeterior. Biodegrad. 2000, 45, 43-47. [CrossRef]

206. Awad, A.H.A. Environmental Study in Subway Metro Stations in Cairo, Egypt. J. Occup. Health 2002, 44, 112-118. [CrossRef]

207. Gilleberg, S.B.; Faull, J.L.; Graeme-Cook, K.A. A preliminary survey of aerial biocontaminants at six London Underground stations. Int. Biodeterior. Biodegrad. 1998, 41, 149-152. [CrossRef]

208. Hwang, S.H.; Ahn, J.K.; Park, J.B. Concentrations of Airborne Fungi and Environmental Factors in the Subway Stations in Seoul, Korea. Korean J. Environ. Health Sci. 2014, 40, 81-87. [CrossRef]

209. Seino, K.; Takano, T.; Nakamura, K.; Watanabe, M. An evidential example of airborne bacteria in a crowded, underground public concourse in Tokyo. Atmos. Environ. 2005, 39, 337-341. [CrossRef]

210. Hoseini, M.; Jabbari, H.; Naddafi, K.; Nabizadeh, R.; Rahbar, M.; Yunesian, M.; Jaafari, J. Concentration and distribution characteristics of airborne fungi in indoor and outdoor air of Tehran subway stations. Aerobiologia 2013, 29, 355-363. [CrossRef]

211. Heo, K.J.; Lee, B.U. Seasonal variation in the concentrations of culturable bacterial and fungal aerosols in underground subway systems. J. Aerosol Sci. 2016, 92, 122-129. [CrossRef]

212. Cho, J.-H.; Paik, N.-W. Assessment of Airborne Fungi Concentrations in Subway Stations in Seoul, Korea. Korean J. Environ. Health Sci. 2009, 35, 478-485. [CrossRef]

213. Hwang, S.H.; Park, W.M.; Ahn, J.K.; Lee, K.J.; Min, K.B.; Park, J.B. Relationship between culturable airborne bacteria concentrations and ventilation systems in underground subway stations in Seoul, South Korea. Air Qual. Atmos. Health 2016, 9, 173-178. [CrossRef]

214. Hwang, S.H.; Yoon, C.S.; Ryu, K.N.; Paik, S.Y.; Cho, J.H. Assessment of airborne environmental bacteria and related factors in 25 underground railway stations in Seoul, Korea. Atmos. Environ. 2010, 44, 1658-1662. [CrossRef]

215. Kim, K.Y.; Park, J.B.; Kim, C.N.; Lee, K.J. Distribution of airborne fungi, particulate matter and carbon dioxide in Seoul metropolitan subway stations. J. Prev. Med. Public Health 2006, 39, 325-330. [PubMed]

216. Dong, S.; Yao, M. Exposure assessment in Beijing, China: Biological agents, ultrafine particles, and lead. Environ. Monit. Assess. 2010, 170, 331-343. [CrossRef]

217. Gładyszewska-Fiedoruk, K.; Krawczyk, D.A. The possibilities of energy consumption reduction and a maintenance of indoor air quality in doctor's offices located in north-eastern Poland. Energy Build. 2014, 85, 235-245. [CrossRef]

218. Siskos, P.A.; Bouba, K.E.; Stroubou, A.P. Determination of Selected Pollutants and Measurement of Physical Parameters for the Evaluation of Indoor Air Quality in School Buildings in Athens, Greece. Indoor Built Environ. 2001, 10, 185-192. [CrossRef]

219. Jeon, J.-S.; Yoon, J.-C.; Lee, H.-C.; Eom, S.-W.; Chae, Y.-Z. A Noticeable Change in Indoor Radon Levels After Platform Screen Doors Installation in Seoul Subway Station. J. Korean Soc. Atmos. Environ. 2012, 28, 59-67. [CrossRef]

220. Kim, D.-S.; Kim, Y.-S. Distributions of Airborne Radon Concentrations in Seoul Metropolitan Subway Stations. Health Phys. 1993, 65, 12-16. [CrossRef]

221. Talaeepour, M.; Moattar, F.; Atabi, F.; Borhan Azad, S.; Talaeepour, A.R. Investigation on Radon Concentration in the Tehran Subway Stations, in Regard with Environmental Effects. J. Appl. Sci. 2006, 6, 1617-1620. [CrossRef]

222. Yoon, S.; Chang, B.-U.; Kim, Y.; Byun, J.-I.; Yun, J.-Y. Indoor radon distribution of subway stations in a Korean major city. J. Environ. Radioact. 2010, 101, 304-308. [CrossRef] [PubMed]

223. TIAN, Y.; TU, J. Experimental Analysis of the Effect on the Air-conditioned Subway Station from the Filter Cleaning. Power Gener. Air Cond. 2012, 1, 92-94.

224. Choi, S.I.; Feng, J.; Kim, S.B.; Jo, Y.M. Magnetization of Metal Mesh for Fine Dust Capture. Aerosol Air Qual. Res. 2018, 18, 1932-1943. [CrossRef]

225. Son, Y.-S.; Dinh, T.-V.; Chung, S.-G.; Lee, J.-H.; Kim, J.-C. Removal of particulate matter emitted from a subway tunnel using magnetic filters. Environ. Sci. Technol. 2014, 48, 2870-2876. [CrossRef]

226. Huang, S.; Zhang, X.; Tafu, M.; Toshima, T.; Jo, Y. Study on subway particle capture by ferromagnetic mesh filter in nonuniform magnetic field. Sep. Purif. Technol. 2015, 156, 642-654. [CrossRef]

227. Son, Y.-S.; Oh, Y.-H.; Choi, I.-Y.; Dinh, T.-V.; Chung, S.-G.; Lee, J.-H.; Park, D.; Kim, J.-C. Development of a magnetic hybrid filter to reduce PM10 in a subway platform. J. Hazard. Mater. 2019, 368, 197-203. [CrossRef] 
228. Han, Z.; Wang, J.; Shao, X.; Zhou, S.; Han, X.; Shi, W. Characteristics and el iminating strategies of contaminants in urban underground spaces. Heat. Vent. Air Cond. 2009, 39, 21-30.

229. Wang, K. Air pollutants impacted by different purification methods of subway air conditioning and ventilation. Shanghai J. Prev. Med. 2018, 30, 539-543.

230. Tokarek, S.; Bernis, A. An exemple of particle concentration reduction in Parisian subway stations by electrostatic precipitation. Environ. Technol. 2006, 27, 1279-1287. [CrossRef]

231. Zhou, H. Present Situation and Prospect of Air Purification Present Situation and Prospect of Air Purification Technology in Shanghai Rail Transpiration System. Environ. Sci. Manag. 2018, 43, 57-62.

232. Son, Y.-S.; Jeong, J.-H.; Lee, H.J.; Kim, J.-C. A novel control system for nitrogen dioxide removal and energy saving from an underground subway stations. J. Clean. Prod. 2016, 133, 212-219. [CrossRef]

233. Moreno, T.; de Miguel, E. Improving air quality in subway systems: An overview. Environ. Pollut. 2018, 239, 829-831. [CrossRef] [PubMed]

234. Cartenì, A.; Cascetta, F. Particulate matter concentrations in a high-quality rubber-tyred metro system: The case study of Turin in Italy. Int. J. Environ. Sci. Technol. 2018, 15, 1921-1930. [CrossRef]

235. Park, J.-H.; Son, Y.-S.; Kim, K.-H. A review of traditional and advanced technologies for the removal of particulate matter in subway systems. Indoor Air 2019, 29, 177-191. [CrossRef]

236. Vilcassim, M.J.R.; Thurston, G.D.; Peltier, R.E.; Gordon, T. Black carbon and particulate matter (PM2.5) concentrations in New York City's subway stations. Environ. Sci. Technol. 2014, 48, 14738-14745. [CrossRef]

237. Mendell, M.J.; Lei-Gomez, Q.; Mirer, A.G.; Seppänen, O.; Brunner, G. Risk factors in heating, ventilating, and air-conditioning systems for occupant symptoms in US office buildings: The US EPA BASE study. Indoor Air 2008, 18, 301-316. [CrossRef]

238. Pickering, C.A.; Moore, W.K.; Lacey, J.; Holford-Strevens, V.; Pepys, J. Investigation of a respiratory disease associated with an air-conditioning system. Clin. Allergy 1976, 6, 109-118. [CrossRef]

239. Möritz, M.; Peters, H.; Nipko, B.; Rüden, H. Capability of air filters to retain airborne bacteria and molds in heating, ventilating and air-conditioning (HVAC) systems. Int. J. Hyg. Environ. Health 2001, 203, 401-409. [CrossRef]

240. Camelli, F.E.; Byrne, G.; Löhner, R. Modeling subway air flow using CFD. Tunn. Undergr. Space Technol. 2014, 43, 20-31. [CrossRef]

241. Yan, W.; Naiping, G.; Lihui, W.; Xiping, W. A numerical analysis of airflows caused by train-motion and performance evaluation of a subway ventilation system. Indoor Built Environ. 2014, 23, 854-863. [CrossRef]

242. Pan, S.; Fan, L.; Liu, J.; Xie, J.; Sun, Y.; Cui, N.; Zhang, L.; Zheng, B. A Review of the Piston Effect in Subway Stations. Adv. Mech. Eng. 2013, 5, 950205. [CrossRef]

243. Ma, J.; Zhang, X.; Li, A.; Deng, B.; Lv, W.; Guo, Y.; Zhang, W.; Huang, L. Analyses of the improvement of subway station thermal environment in northern severe cold regions. Build. Environ. 2018, 143, 579-590. [CrossRef]

244. Zhang, H.; Cui, T.; Liu, M.; Zheng, W.; Zhu, C.; You, S.; Zhang, Y. Energy performance investigation of an innovative environmental control system in subway station. Build. Environ. 2017, 126, 68-81. [CrossRef]

245. Li, J.; Lu, S.; Wang, Q.; Tian, S.; Jin, Y. Study of Passive Adjustment Performance of Tubular Space in Subway Station Building Complexes. Appl. Sci. 2019, 9, 834. [CrossRef]

246. Tsukahara, M.; Koshiba, Y.; Ohtani, H. Effectiveness of downward evacuation in a large-scale subway fire using Fire Dynamics Simulator. Tunn. Undergr. Space Technol. 2011, 26, 573-581. [CrossRef]

247. Zhou, Y.; Bu, R.; Gong, J.; Xu, Z.; Chen, H.; Fan, C. Numerical investigation on the effectiveness of positive pressure ventilation technology in a multi-layer subway station. Indoor Built Environ. 2018, 31. [CrossRef]

248. James, C.; Markus, B. Towards a dynamic evacuation system developing methodologies to simulate the evacuation capabilities of subway stations in response to a terrorist attack with CBRNE weapons. Chin. J. Burns Wounds Surf. Ulcers 2014, 1, 109-118.

249. Ji, J.; Zhong, W.; Li, K.Y.; Shen, X.B.; Zhang, Y.; Huo, R. A simplified calculation method on maximum smoke temperature under the ceiling in subway station fires. Tunn. Undergr. Space Technol. 2011, 26, 490-496. [CrossRef]

250. Chen, F.; Chien, S.-W.; Jang, H.-M.; Chang, W.-J. Stack effects on smoke propagation in subway stations. Contin. Mech. Thermodyn. 2003, 15, 425-440. [CrossRef]

251. Roh, J.S.; Ryou, H.S.; Park, W.H.; Jang, Y.J. CFD simulation and assessment of life safety in a subway train fire. Tunn. Undergr. Space Technol. 2009, 24, 447-453. [CrossRef] 
252. Pflitsch, A.; Brüne, M.; Ringeis, J.; Killing-Heinze, M. ORGAMIR—Development of a Safety System for Reaction of an Event with Emission of Hazardous Airborne Substances—Like a Terror Attack or Fire-Based on Subway Climatology. In Proceedings of the Fourth International Symposium on Tunnel Safety and Security, Frankfurt am Main, Germany, 17-19 March 2010.

253. Brüne, M.; Pflitsch, A.; Agnew, B.; Spiegel, J. (Eds.) Dynamics of Natural Air Flow inside Subway Tunnels. In Proceedings of the Fifth International Symposium on Tunnel Safety and Security, New York, NY, USA, 14-16 March 2012.

254. Rie, D.-H.; Hwang, M.-W.; Kim, S.-J.; Yoon, S.-W.; Ko, J.-W.; Kim, H.-Y. A study of optimal vent mode for the smoke control of subway station fire. Tunn. Undergr. Space Technol. 2006, 21, 300-301. [CrossRef]

255. Khaleghi, M.; Talaee, M.R. Analysis of unsteady air flow in the subway station influenced by train movement. Sci. Technol. Built Environ. 2019, 1-10. [CrossRef]

256. Ren, C.; Feng, Z.; Cen, D.; Cao, S.-J. Study on the subway environment induced by moving train using Gaussian distributed momentum source theory method. Indoor Built Environ. 2018, 21. [CrossRef]

257. Wang, J.; Zhao, L.; Zhu, D.; Gao, H.O.; Xie, Y.; Li, H.; Xu, X.; Wang, H. Characteristics of particulate matter (PM) concentrations influenced by piston wind and train door opening in the Shanghai subway system. Transp. Res. Part D Transp. Environ. 2016, 47, 77-88. [CrossRef]

258. Martins, V.; Moreno, T.; Minguillón, M.C.; Amato, F.; de Miguel, E.; Capdevila, M.; Querol, X. Exposure to airborne particulate matter in the subway system. Sci. Total Environ. 2015, 511, 711-722. [CrossRef]

259. Huang, Y.-D.; Gong, X.-L.; Peng, Y.-J.; Lin, X.-Y.; Kim, C.-N. Effects of the ventilation duct arrangement and duct geometry on ventilation performance in a subway tunnel. Tunn. Undergr. Space Technol. 2011, 26, 725-733. [CrossRef]

260. Kim, J.-Y.; Kim, K.-Y. Effects of vent shaft location on the ventilation performance in a subway tunnel. J. Wind Eng. Ind. Aerodyn. 2009, 97, 174-179. [CrossRef]

261. Xue, P.; You, S.; Chao, J.; Ye, T. Numerical investigation of unsteady airflow in subway influenced by piston effect based on dynamic mesh. Tunn. Undergr. Space Technol. 2014, 40, 174-181. [CrossRef]

262. López González, M.; Galdo Vega, M.; Fernández Oro, J.M.; Blanco Marigorta, E. Numerical modeling of the piston effect in longitudinal ventilation systems for subway tunnels. Tunn. Undergr. Space Technol. 2014, 40, 22-37. [CrossRef]

263. Yang, W.C.; Peng, L.M.; Shi, C.H.; Hu, Z.L. Numerical Simulation on Ventilation Effect of Train-Induced Wind in Subway. Appl. Mech. Mater. 2013, 444-445, 450-454. [CrossRef]

264. Huang, Y.-D.; Gao, W.; Kim, C.-N. A Numerical Study of the Train-Induced Unsteady Airflow in a Subway Tunnel with Natural Ventilation Ducts Using the Dynamic Layering Method. J. Hydrodyn. 2010, 22, 164-172. [CrossRef]

265. Huang, Y.-D.; Li, C.; Kim, C.N. A Numerical Analysis of the Ventilation Performance for Different Ventilation Strategies in a Subway Tunnel. J. Hydrodyn. 2012, 24, 193-201. [CrossRef]

266. Yao, Y.; Zhang, S.; Shi, L.; Cheng, X. Effects of shaft inclination angle on the capacity of smoke exhaust under tunnel fire. Indoor Built Environ. 2019, 28, 77-87. [CrossRef]

267. Chen, F.; Guo, S.-C.; Chuay, H.-Y.; Chien, S.-W. Smoke Control of Fires in Subway Stations. Theor. Comput. Fluid Dyn. 2003, 16, 349-368. [CrossRef]

268. Pflitsch, A.; Brüne, M.; Killing-Heinze, M.; Ringeis, J.; Agnew, B.; Steiling, B. Natural Ventilation as a Factor Controlling the Dispersal of Airborne Toxins in Subway Systems in a Disaster Situation. J. Transp. Saf. Secur. 2013, 5, 78-92. [CrossRef]

269. Spengler, J.D.; Chen, Q. Indoor air quality factors in designing a healthy building. Annu. Rev. Energy. Environ. 2000, 25, 567-600. [CrossRef]

270. Sun, Y.; Yin, H.; Chen, T.; Wu, R.; Li, A. Ventilation effectiveness and human thermal comfort of displacement ventilation mode based on square column attachment. Heat. Vent. Air Cond. 2018, 48, 105-110.

271. Yin, H.; Li, A.; Liu, Z.; Sun, Y.; Chen, T. Experimental study on airflow characteristics of a square column attached ventilation mode. Build. Environ. 2016, 109, 112-120. [CrossRef]

272. Moreno, T.; Reche, C.; Minguillón, M.C.; Capdevila, M.; de Miguel, E.; Querol, X. The effect of ventilation protocols on airborne particulate matter in subway systems. Sci. Total Environ. 2017, 584-585, 1317-1323. [CrossRef]

273. Kim, G.-S.; Son, Y.-S.; Lee, J.-H.; Kim, I.-W.; Kim, J.-C.; Oh, J.-T.; Kim, H. Air Pollution Monitoring and Control System for Subway Stations Using Environmental Sensors. J. Sens. 2016, 2016, 1-10. [CrossRef] 
274. Son, Y.-S.; Jeon, J.-S.; Lee, H.J.; Ryu, I.-C.; Kim, J.-C. Installation of platform screen doors and their impact on indoor air quality: Seoul subway trains. J. Air Waste Manag. Assoc. 2014, 64, 1054-1061. [CrossRef] [PubMed]

275. Juraeva, M.; Ryu, K.J.; Jeong, S.-H.; Song, D.J. Numerical optimization study to install air curtain in a subway tunnel by using design of experiment. J. Mech. Sci. Technol. 2014, 28, 183-190. [CrossRef]

276. Krasyuk, A.M.; Lugin, I.V.; Pavlov, S.A. Experimental research into air distribution in a terminal subway station. Tunn. Undergr. Space Technol. 2019, 85, 21-28. [CrossRef]

277. He, S.; Jin, L.; Le, T.; Zhang, C.; Liu, X.; Ming, X. Commuter health risk and the protective effect of three typical metro environmental control systems in Beijing, China. Transp. Res. Part. D Transp. Environ. 2018, 62, 633-645. [CrossRef]

278. Han, H.; Lee, J.-Y.; Jang, K.-J. Effect of platform screen doors on the indoor air environment of an underground subway station. Indoor Built Environ. 2015, 24, 672-681. [CrossRef]

279. Son, Y.-S.; Salama, A.; Jeong, H.-S.; Kim, S.; Jeong, J.-H.; Lee, J.; Sunwoo, Y.; Kim, J.-C. The Effect of Platform Screen Doors on PM10 Levels in a Subway Station and a Trial to Reduce PM10 in Tunnels. Asian J. Atmos. Environ. 2013, 7, 38-47. [CrossRef]

280. Kim, K.-H.; Ho, D.X.; Jeon, J.-S.; Kim, J.-C. A noticeable shift in particulate matter levels after platform screen door installation in a Korean subway station. Atmos. Environ. 2012, 49, 219-223. [CrossRef]

281. Lee, J.G.; Byeon, S.H.; Lee, J.H. The effect of platform screen door (PSD) for fine particles at subway train in Seoul, Korea. In Proceedings of the 2009 ICCAS-SICE, Fukuoka, Japan, 18-21 August 2009.

282. Kim, Y.S.; Kim, M.H.; Kim, S.J.; Kim, I.W.; Jeon, J.S.; Yoo, C.K. Multidimensional interpretation of the air quality change by the installation of PSD in a subway station. In Proceedings of the 2009 ICCAS-SICE, Fukuoka, Japan, 18-21 August 2009.

283. Yang, Z.; Su, X.; Ma, F.; Yu, L.; Wang, H. An innovative environmental control system of subway. J. Wind Eng. Ind. Aerodyn. 2015, 147, 120-131. [CrossRef]

284. Zhao, L.; Wang, J.; Gao, H.O.; Xie, Y.; Jiang, R.; Hu, Q.; Sun, Y. Evaluation of particulate matter concentration in Shanghai's metro system and strategy for improvement. Transp. Res. Part. D Transp. Environ. 2017, 53, 115-127. [CrossRef]

285. Zhang, X.; Ma, J.; Li, A.; Lv, W.; Zhang, W.; Yang, C.; Deng, B. Train-induced unsteady airflow effect analysis on a subway station using field experiments and numerical modelling. Energy Build. 2018, 174, 228-238. [CrossRef]

286. Qu, L.; Chow, W.K. Platform screen doors on emergency evacuation in underground railway stations. Tunn. Undergr. Space Technol. 2012, 30, 1-9. [CrossRef]

287. Yuan, F.-D.; You, S.-J. CFD simulation and optimization of the ventilation for subway side-platform. Tunn. Undergr. Space Technol. 2007, 22, 474-482. [CrossRef]

288. Wang, L.; Li, Z.; Du, X.; Tang, D.; Shen, L. A measurement analysis of subway thermal environment characteristics of the coupling airflow between air-conditioning air supply and piston wind. J. Chongqing Univ. 2011, 34, 116-122.

289. Wang, L.; Du, Z.; Zhang, J.; Chen, R.; Yu, S.; Qu, M. Study on the thermal comfort characteristics under the vent with supplying air jets and cross-flows coupling in subway stations. Energy Build. 2016, 131, 113-122. [CrossRef]

290. Gao, R.; Li, A.; Hao, X.; Lei, W.; Zhao, Y.; Deng, B. Fire-induced smoke control via hybrid ventilation in a huge transit terminal subway station. Energy Build. 2012, 45, 280-289. [CrossRef]

291. Teodosiu, C.I.; Ilie, V.; Dumitru, R.G.; Teodosiu, R.S. Assessment of ventilation efficiency for emergency situations in subway systems by CFD modeling. Build. Simul. 2016, 9, 319-334. [CrossRef]

292. Yan, S.X.; Wu, X.P.; Wang, D. Study of the Performance of Smoke Control under Non-uniform Smoke Exhaust Velocity. Procedia Eng. 2011, 11, 385-393. [CrossRef]

293. Yi, L.; Wei, R.; Peng, J.; Ni, T.; Xu, Z.; Wu, D. Experimental study on heat exhaust coefficient of transversal smoke extraction system in tunnel under fire. Tunn. Undergr. Space Technol. 2015, 49, 268-278. [CrossRef]

294. Giachetti, B.; Couton, D.; Plourde, F. Smoke spreading analyses in a subway fire scale model. Tunn. Undergr. Space Technol. 2017, 70, 233-239. [CrossRef]

295. Li, Q.; Loy-Benitez, J.; Heo, S.; Lee, S.; Liu, H.; Yoo, C. Flexible real-time ventilation design in a subway station accommodating the various outdoor PM10 air quality from climate change variation. Build. Environ. 2019, 153, 77-90. [CrossRef] 
296. Jeong, I.C.; Li, G.H.; Kim, N.G.; Lim, S.B. An integrated monitoring and controlling system for subway system. In Proceedings of the 2011 2nd International Conference on Engineering and Industries (ICEI), Jeju, Korea, 29 November-1 December 2011.

297. Liu, H.; Lee, S.; Kim, M.; Shi, H.; Kim, J.T.; Wasewar, K.L.; Yoo, C. Multi-objective optimization of indoor air quality control and energy consumption minimization in a subway ventilation system. Energy Build. 2013, 66, 553-561. [CrossRef]

298. Di Perna, C.; Carbonari, A.; Ansuini, R.; Casals, M. Empirical approach for real-time estimation of air flow rates in a subway station. Tunn. Undergr. Space Technol. 2014, 42, 25-39. [CrossRef]

299. Loy-Benitez, J.; Li, Q.; Ifaei, P.; Nam, K.; Heo, S.; Yoo, C. A dynamic gain-scheduled ventilation control system for a subway station based on outdoor air quality conditions. Build. Environ. 2018, 144, 159-170. [CrossRef]

300. Kim, M.; Liu, H.; Kim, J.T.; Yoo, C. Evaluation of passenger health risk assessment of sustainable indoor air quality monitoring in metro systems based on a non-Gaussian dynamic sensor validation method. J. Hazard. Mater. 2014, 278, 124-133. [CrossRef]

301. Lee, S.; Liu, H.; Kim, M.; Kim, J.T.; Yoo, C. Online monitoring and interpretation of periodic diurnal and seasonal variations of indoor air pollutants in a subway station using parallel factor analysis (PARAFAC). Energy Build. 2014, 68, 87-98. [CrossRef]

302. Liu, H.; Kim, M.; Kang, O.; SankaraRao, B.; Kim, J.; Kim, J.-C.; Yoo, C.K. Sensor Validation for Monitoring Indoor Air Quality in a Subway Station. Indoor Built Environ. 2012, 21, 205-221. [CrossRef]

303. Liu, X.; Liu, J. Study on the Application of VAV based Relative Warmth Index (RWI) Running Mode in Guangzhou Subway. Build. Sci. 2007, 23, 78-82.

304. Fu, Q.; Feng, L.; Yuan, Z. Simulation Analysis of Energy Consumption of VAV Air Conditioning System in Subway Station. Refrig. Air Cond. 2019, 33, 21-24, 39.

305. Marzouk, M.; Abdelaty, A. Monitoring thermal comfort in subways using building information modeling. Energy Build. 2014, 84, 252-257. [CrossRef]

306. Kim, Y.-S.; Kim, J.T.; Kim, I.-W.; Kim, J.-C.; Yoo, C. Multivariate Monitoring and Local Interpretation of Indoor Air Quality in Seoul's Metro System. Environ. Eng. Sci. 2010, 27, 721-731. [CrossRef]

307. Liu, H.; Huang, M.; Janghorban, I.; Ghorbannezhad, P.; Yoo, C. Faulty sensor detection, identification and reconstruction of indoor air quality measurements in a subway station. In Proceedings of the 2011 11th International Conference on Control, Automation and Systems, Gyeonggi-do, Korea, 26-29 October 2011.

308. Zhang, R.; Ravi, D.; Yang, G.-Z.; Lo, B. A personalized air quality sensing system-A preliminary study on assessing the air quality of London underground stations. In Proceedings of the 2017 IEEE 14th International Conference on Wearable and Implantable Body Sensor Networks (BSN), Eindhoven, The Netherlands, 9-12 May 2017; IEEE: New York, NY, USA, 2017; pp. 111-114, ISBN 978-1-5090-6244-7.

309. Tao, Z.; Wang, Y.; Zou, C.; Li, Q.; Luo, Y. Assessment of ventilation noise impact from metro depot with over-track platform structure on workers and nearby inhabitants. Environ. Sci. Pollut. Res. Int. 2019, 26, 9203-9218. [CrossRef] [PubMed]

310. Śliwińska-Kowalska, M.; Zaborowski, K. WHO Environmental Noise Guidelines for the European Region: A Systematic Review on Environmental Noise and Permanent Hearing Loss and Tinnitus. Int. J. Environ. Res. Public Health 2017, 14, 1139. [CrossRef] [PubMed]

311. Wang, P.; Wang, Y.; Zou, C.; Guo, J. A preliminary investigation of noise impact within metro stations in the urban city of Guangzhou, China. Environ. Sci. Pollut. Res. Int. 2017, 24, 11371-11382. [CrossRef]

312. Jiang, H.; Jin, H. Analysis and Control on Noise in Subway Stations. Huazhong Archit. 2011, 2, $65-67$.

313. Aly, M.E. Noise assessment inside the Greater Cairo Underground second-line Metro. Sadhana 2005, 30, 47-55. [CrossRef]

314. Gershon, R.R.M.; Neitzel, R.; Barrera, M.A.; Akram, M. Pilot survey of subway and bus stop noise levels. J. Urban. Health 2006, 83, 802-812. [CrossRef]

315. Babisch, W.; Fromme, H.; Beyer, A.; Ising, H. Increased catecholamine levels in urine in subjects exposed to road traffic noise. Environ. Int. 2001, 26, 475-481. [CrossRef]

316. Rylander, R. Noise, stress and annoyance. Noise Notes 2006, 5, 35-40. [CrossRef]

317. Hamidi, M.; Kavousi, A.; Zaheri, S.; Hamadani, A.; Mirkazemi, R. Assessment of the noise annoyance among subway train conductors in Tehran, Iran. Noise Health 2014, 16, 177-182. [CrossRef]

318. Gomez-Agustina, L.; Dance, S.; Shield, B. The effects of air temperature and humidity on the acoustic design of voice alarm systems on underground stations. Appl. Acoust. 2014, 76, 262-273. [CrossRef] 
319. Mao, P.; Li, J.; Xiong, L.; Wang, R.; Wang, X.; Tan, Y.; Li, H. Characterization of Urban Subway Microenvironment Exposure-A Case of Nanjing in China. Int. J. Environ. Res. Public Health 2019, 16, 625. [CrossRef] [PubMed]

320. European Commission. Recommendations for Life Cycle Impact Assessment in the European Context. Based on Existing Environmental Impact Assessment Models and Factors; Publications Office of the European Union: Luxembourg, 2011; Available online: https://publications.jrc.ec.europa.eu/repository/handle/JRC61049 (accessed on 7 February 2020).

321. Shi, S.; Bian, Y.; Zhang, L.; Chen, C. A method for assessing the performance of nanofiber films coated on window screens in reducing residential exposures to PM2.5 of outdoor origin in Beijing. Indoor Air 2017, 27, 1190-1200. [CrossRef] [PubMed]

322. Gao, R.; Li, A.; Hao, X.; Lei, W.; Deng, B. Prediction of the spread of smoke in a huge transit terminal subway station under six different fire scenarios. Tunn. Undergr. Space Technol. 2012, 31, 128-138. [CrossRef]

C 2020 by the authors. Licensee MDPI, Basel, Switzerland. This article is an open access article distributed under the terms and conditions of the Creative Commons Attribution (CC BY) license (http://creativecommons.org/licenses/by/4.0/). 